Review

\title{
Potential for Introduction of Bat-Borne Zoonotic Viruses into the EU: A Review
}

\author{
Robin R. L. Simons *, Paul Gale, Verity Horigan, Emma L. Snary and Andrew C. Breed \\ Animal Health and Veterinary Laboratories Agency (AHVLA), Epidemiology, \\ Surveillance \& Risk Group, New Haw, Surrey, Addlestone KT15 3NB, UK; \\ E-Mails: paul.gale@ahvla.gsi.gov.uk (P.G.), verity.horigan@ahvla.gsi.gov.uk (V.H.), \\ emma.snary@ahvla.gsi.gov.uk (E.L.S.), andrew.breed@ahvla.gsi.gov.uk (A.C.B.)
}

* Author to whom correspondence should be addressed; E-Mail: robin.simons@ahvla.gsi.gov.uk; Tel.: +44-01932-357-837; Fax: +44-01932-357-445.

Received: 7 February 2014; in revised form: 10 April 2014 / Accepted: 6 May 2014 /

Published: 16 May 2014

\begin{abstract}
Bat-borne viruses can pose a serious threat to human health, with examples including Nipah virus (NiV) in Bangladesh and Malaysia, and Marburg virus (MARV) in Africa. To date, significant human outbreaks of such viruses have not been reported in the European Union (EU). However, EU countries have strong historical links with many of the countries where NiV and MARV are present and a corresponding high volume of commercial trade and human travel, which poses a potential risk of introduction of these viruses into the EU. In assessing the risks of introduction of these bat-borne zoonotic viruses to the EU, it is important to consider the location and range of bat species known to be susceptible to infection, together with the virus prevalence, seasonality of viral pulses, duration of infection and titre of virus in different bat tissues. In this paper, we review the current scientific knowledge of all these factors, in relation to the introduction of $\mathrm{NiV}$ and MARV into the EU.
\end{abstract}

Keywords: bats; viruses; Nipah; Marburg; European Union; risk

\section{Introduction}

Bat-borne viruses with pandemic potential have been identified as the origin of a number of recent human disease outbreaks. Examples include the paramyxoviruses Nipah virus (NiV) in Malaysia and 
Bangladesh [1] and Hendra virus $(\mathrm{HeV})$ in Australia [2] and the filoviruses Ebola (EBOV) and Marburg viruses (MARV) in Africa [3]. Bats have also been linked with the more recent Middle East respiratory syndrome coronavirus (MERS-CoV) [4,5]. Nipah Virus, in particular, has been suggested to have pandemic potential as it is capable of limited human-human transmission and RNA viruses in general have particularly high mutation rates. A human-adapted strain of $\mathrm{NiV}$, were it to emerge in Asia, could spread rapidly due to high population densities and global interconnectedness [1]. A large, and still increasing, number of different viruses have been isolated from bats, many of which are asymptomatic in the host and are closely related to human pathogens. These viruses have the potential for cross-species transmission (i.e., "spillover") to other mammalian species, for example, MARV in monkeys [6] and $\mathrm{NiV}$ in pigs [7], and to directly or indirectly infect humans [2]. A recent paper describes the infection of a wildlife biologist with a novel paramyxovirus during a field trip to South Sudan and Uganda [8]. A recent study found that bats have, on average, significantly more zoonotic viruses per species than rodents, which are also known to host a large range of viruses [9]. Additionally, the authors estimated that viruses had a broader host range in bats, averaging 4.51 host species per virus. Bat-borne paramyxoviruses have been identified in various bat species across Africa, Australia, South America and Asia and recently the detection and characterization of paramyxoviruses in free-ranging European bats has also been reported [10]. Further to this, recent evidence places bats as tentative hosts at ancestral nodes to Paramyxoviridae and Pneumoviridae [11]. Bat species can have very broad geographic ranges $[9,12]$ and multiple species can share the same habitats and even roost sites [13]. Studies of Pteropus bats in Australia and Asia found they could travel hundreds of kilometers between roosting sites with their home ranges extending across national boundaries and over sea $[14,15]$.

Factors that affect the degree and rate of contact between animals and humans are important for spillover of any zoonotic emerging infectious disease. Most human outbreaks of bat-borne zoonotic diseases have been suggested to be as a consequence of human activities. For example, outbreaks of MARV in Africa have been linked to human contact with bat caves, for reasons such as mining operations [16] or tourism [17,18]. Deforestation has also led to bat colonies moving closer to areas inhabited by humans in search of food and roosting sites [19]. Bats are known to have varying degrees of contact with domestic animals and commercial food crops [20,21], in particular contact of Pteropus giganteus bats with date palm sap producing trees in Bangladesh is considered a risk factor for human $\mathrm{NiV}$ infection [22]. Livestock can act as an intermediate host between bats and humans. The outbreak of NiV in Malaysia in 1998 was linked to infection of pigs via fruit bats and resulted in the culling of over one million pigs and the deaths of over 100 people [7]. Similarly, in Australia Hendra virus is transmitted to humans via horses; to date 82 horses and seven people have been infected (four people have died). Bats themselves are a known food source for humans in some areas of Africa [23] and Asia [24,25].

While bats in the European Union (EU) are known to harbor zoonotic viruses that can be transmitted via close contact, such as the European bat Lyssaviruses 1 and 2 (EBLV1 and 2), there is currently no confirmation of the presence of viruses with pandemic potential in bats in the EU (i.e., at least capable of sustained human-human transmission). However, it is important to note that this should not be taken as proof of absence of such viruses, but rather that they have not been detected during surveillance of bat populations in the EU to date. Historically, the first reports of human MARV 
cases were in laboratory workers in Germany and Yugoslavia in 1967, through direct contact with blood from African green monkeys (Cercopithecus aethiops) imported from Uganda [6,26]. However, more recent cases of bat-borne viruses affecting humans in the EU have been isolated incidents, notably the case of a Dutch tourist returning from Uganda after visiting a bat cave in which MARV-infected bats roost [17,18]. Similarly, as of November 2013, 10 cases of MERS-CoV have been detected in Europe [27], several clusters of which represent chains of transmission in which the primary case had been infected in the Middle East. Previous studies have demonstrated the presence of similar viruses in EU bat populations, suggesting there is a risk of spillover of related viruses in the future. The first filovirus discovered in Europe that was not directly imported from an endemic area of Africa was Lloviu virus (LLOV), detected in dead insectivorous bats in massive bat die-offs in caves in Spain in 2002 [28]. Simultaneous bat die-offs were observed in Portugal and France, although a causal relationship between LLOV and mortality was not shown.

Countries in the EU have strong historical links with many of the countries where zoonotic bat-borne viruses such as NiV and MARV are present and, consequently, commercial trade and human travel pose a potential route of introduction of such viruses into the EU. Many patients in the 2007 EBOV outbreak in Uganda presented with mild clinical symptoms raising concerns that travel is possible whilst infected, [29]. Other factors, such as the importation of bushmeat, including bats and body parts of primates [29], could be potential routes of virus introduction. A qualitative risk assessment for the introduction of henipaviruses to the UK concluded that there was a low level of risk from Southern Asia, South-East Asia and Australia, through import of fruit and bushmeat and a very low level of risk through import of bat meat, horses and companion animals and through human travel [30]. However, the assessment highlighted the high levels of uncertainty, reflecting the limited data and specific details of the routes involved. A risk assessment for NiV establishing in Australia also identified a lack of relevant data in various areas, reflected in the high levels of uncertainty in the risk estimates [31].

In this paper we review the scientific literature relating to the risk of introduction of $\mathrm{NiV}$ and MARV into the EU, but do not formally assess the risk. We begin by reviewing the current evidence for the geographical location of the viruses and thus where a potential risk of introduction to EU Member States (MSs) may exist. Next, we review the evidence for factors which may affect the probability of an EU introduction via the various routes, such as prevalence and transmission dynamics in bat species and survival and transmission potential of the viruses. Finally we review the evidence directly relating to potential routes for introduction into the EU. The main routes we consider in detail are human travel, trade of fruit and pig products and illegal importation of bushmeat. Other routes such as bat migration, the unintentional introduction of living or dead bats by aircraft and the effect of climate change are also given consideration.

\section{Virus Distribution and Dynamics}

\subsection{Infection in Humans and Associated Risk Factors}

Identification of countries which have had human cases of NiV or MARV is important for assessing the risk of introduction to the EU, as it identifies the areas from which human travel may be a 
particular risk. Knowledge of the risk factors regarding human infection in these countries is also of relevance as they may suggest other potential routes of introduction, highlight similar factors which are present in the EU and may facilitate spread of the viruses, or indicate potential control measures.

NiV: Studies suggest that human outbreaks are linked to one of two distinct Nipah virus strains; NiV-Malaysia or NiV-Bangladesh [32-34]. The Malaysian strain emerged in 1998 with an outbreak in commercially farmed pigs, resulting in $>250$ human cases reported in Malaysia and Singapore with a case-fatality rate approaching 40\% [33]. Pteropus vampyrus and Pteropus hypomelanus were subsequently identified as likely natural reservoir hosts for the virus [35,36]. In this instance, pigs were implicated as amplifier hosts with viral isolates from both sick pigs and humans showing identical nucleotide sequences [7]. The presence of large commercial pig farms with fruit trees in the vicinity meant that foraging bats could drop partially eaten fruit contaminated with NiV into pig farms. Pigs could then have access to this fruit and become infected with NiV [37]. Transmission was attributed to direct contact with infective excretions and secretions and viral spread among pig farms was due to movement of pigs [38]. There were no reported incidences of human-human transmission and there have been no further acute human cases attributed to NiV-Malaysia since 1999, although relapsed and late onset cases have been reported [39]. Laws in Malaysia preventing fruit farming in pig farming areas may have prevented further $\mathrm{NiV}$ outbreaks. In contrast, there have been regular seasonal outbreaks of NiV-Bangladesh since its apparent emergence in 2001, predominantly in Bangladesh, although two outbreaks have also been reported in West Bengal, India, close to the border of Bangladesh [40]. Up to January 2014, there have been 304 reported human cases linked to NiV-Bangladesh with 232 deaths, giving a reported case fatality rate of $76 \%$ [40,41].This appears much higher than the case-fatality rate of NiV-Malaysia, although direct comparison may be complicated by various biases such as method of surveillance and reporting. While human-human transmission is considered a major pathway for human infection with this strain [42], studies in India and Bangladesh suggest the main risk factor is consumption of raw date palm sap [22,43,44]. Date palm sap is harvested from December through to March by cutting into the tree trunk and allowing the sap to flow overnight into an open clay pot [37]. Infrared camera studies have demonstrated that $P$. giganteus bats frequently visit date palm sap trees and lick the sap during collection [45], potentially contaminating it with $\mathrm{NiV}$ from saliva and/or urine. Other reported risk factors for human infection include consumption of alcoholic beverages made from date palm sap [46,47], climbing trees and contact with other NiV infected patients [48] or animals [49]. A recent study investigating the role of landscape factors in NiV spillover risk in Bangladesh [50] found a significant correlation between NiV spillover and villages with higher human population density, more fragmented forest cover and P. giganteus roost sites containing the tree species Polyalithia longifolia or Bombax ceiba.

The geographical distribution of cases within Bangladesh is shown in Figure 1. Cases generally occur in areas near inland water, predominantly the Ganges, which provides a suitable habitat for date palm trees. In 2013, there were cases reported from 14 districts, more than in any other year, but generally only a few cases per district; the largest number was five cases reported from Manikganj [41]. The pattern of cases suggests multiple small outbreaks in different regions, rather than large outbreaks caused by one source. 
Figure 1. Bangladesh districts reporting human Nipah virus (NiV) incidents (coloured in red) by year, based on available data [40,41].
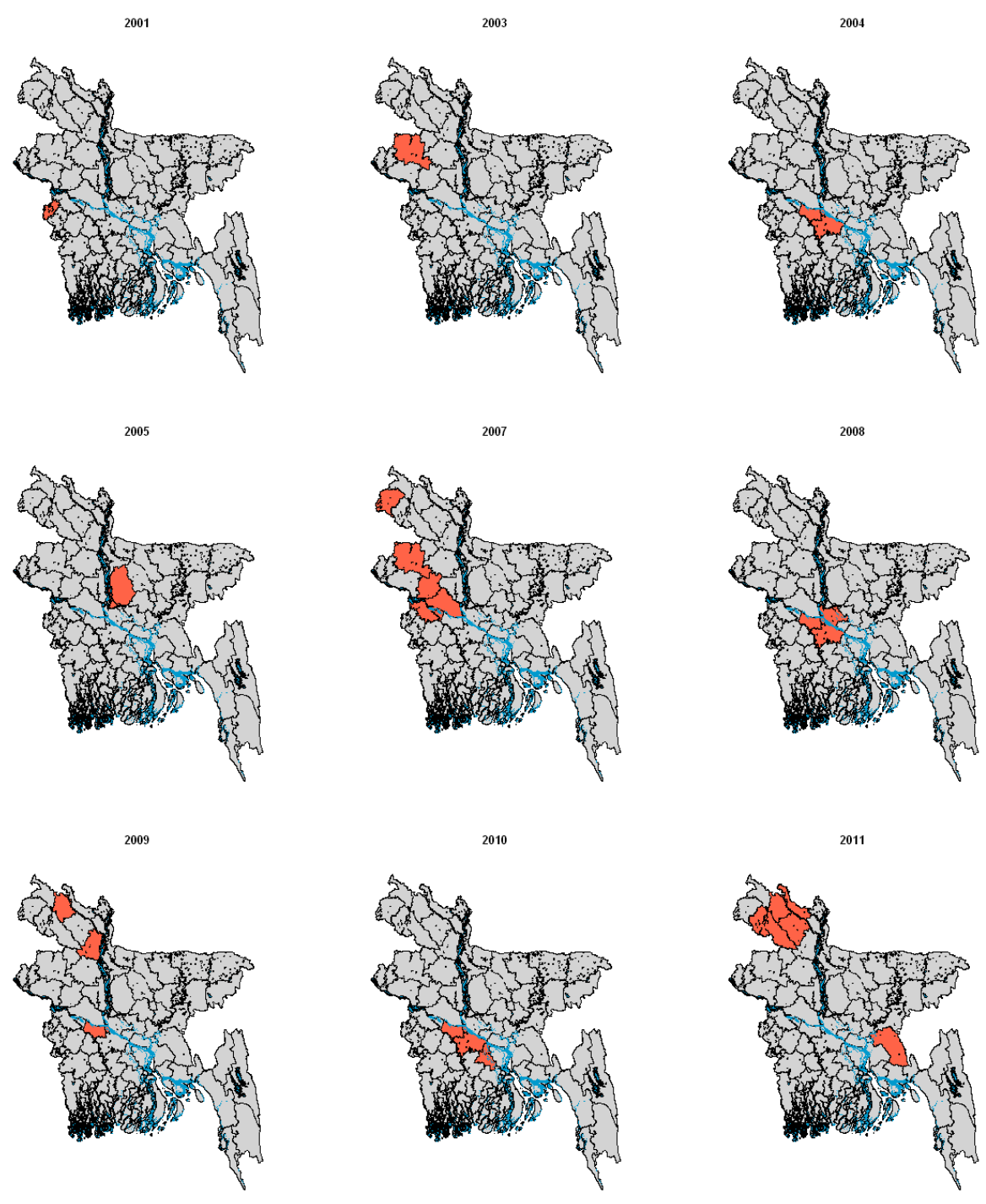

2012

2013
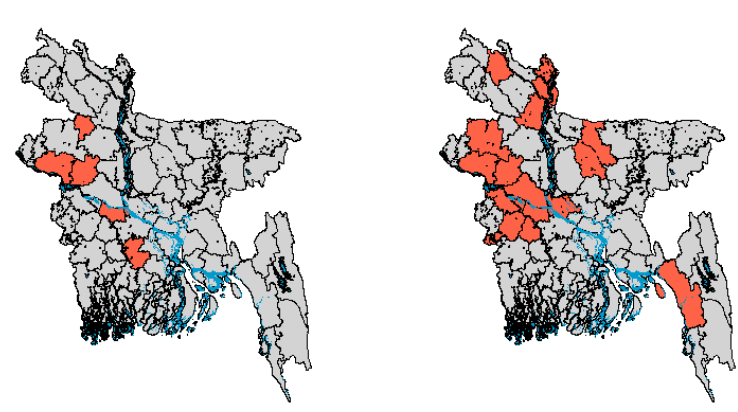

Initial laboratory investigations at the time of the NiV outbreak in Siliguri (India) in 2001 did not identify an infectious agent. Retrospective analysis, however, identified the presence of NiV antibodies in serum samples by enzyme-linked immunosorbent assay (ELISA) and RNA by real-time PCR (RT-PCR) in (stored) urine samples [46,51]. Sequence analysis confirmed that the PCR products were more closely related to the Bangladesh strain (97.5\% identity) than the Malaysia strain. To date, there is no reported evidence of $\mathrm{NiV}$ outbreaks in humans emerging in other parts of India or in any other 
countries. However, given the delay in identification of the Siliguri outbreak and large distribution of bats that can carry $\mathrm{NiV}$, it is possible that more human cases have occurred where NiV has not been detected or reported. Additionally, surveillance for NiV in Bangladesh may be more sensitive due to the previous cases reported to the authorities each year. As such, wider geographical distribution of human cases of NiV should not be ruled out.

MARV: Since the 1967 outbreak of MARV in laboratory workers in Europe [6], outbreaks have been confined to sub-Saharan Africa, although there have been reported cases of individuals acquiring infection in Uganda and then travelling to the Netherlands [18] and the USA [52]. Human cases of filovirus infection in Africa have been associated with hunting fruit bats for meat and with entry to mines or caves where large populations of fruit bat species, such as Rousettus aegyptiacus, are present $[18,53,54]$. It has been suggested that human infection could be through exposure to the excretions from bats roosting in the caves [52], although an experimental study on R. aegyptiacus bats inoculated with the Hogan MARV strain (originally from the South Africa outbreak [55]) did not detect virus in the faeces of infected bats [56]. One study reported "working as a miner" as a significant risk factor for a positive antibody result to MARV, with $87 \%$ of the population who tested positive for Marburg antibodies working in the local gold mines [16]. There has not been a direct food consumption transmission route reported for MARV, although index cases of filovirus infection have often had suspected contact with dead primates found in the forest, with exposure thought to occur during the butchering process $[29,57]$ and the hunting process, which may involve the use of shotguns, potentially causing spray of body tissue and fluids [53].

\subsection{Infection in Bats}

Identification of countries where $\mathrm{NiV}$ and MARV have been detected in bats is important to understand the potential for infected bats from these areas to directly enter the EU, contaminated trade products destined for the EU, or infected humans who may travel to the EU. Knowledge of the species of bats that are susceptible to $\mathrm{NiV}$ and MARV is also a relevant factor for assessing the susceptibility of bat species present in the EU.

There is a growing body of literature on the geographical distribution and range of NiV and MARV in animal species with particular reference to bats. A complicating factor in defining the range is that studies in bats typically report serological or RNA detection results, rather than detection of infectious virus. While a seropositive result is strong evidence of historical exposure to a virus, there may be cross reactivity with related viruses, precluding exact identification of the virus to which exposure has occurred, as seen for $\mathrm{NiV}$ and $\mathrm{HeV}$ in Australasia [58]. Detection of RNA demonstrates the presence of genetic material, but does not prove current presence of infectious virus. Additionally, there can be difficulties in using serological assays outside their original, validated scope, for example when an existing assay is used with samples from an alternative species [59]. Here, the absence of positive and negative control samples and "gold standard" diagnostic assays makes it hard to determine an appropriate cutoff point to distinguish between seropositive and seronegative individuals [60]. As such, positive identifications do not confirm active virus infection at the current time and, in some cases, could only be an indication of historical exposure to a related virus. In the absence of virus 
isolation or full genomic characterization, it cannot, therefore, be definitely confirmed whether the virus is currently present.

NiV: Table 1 shows a summary of reported testing for NiV in bat species. NiV is predominately associated with Asian fruit bats of the genus Pteropus, which have been suggested as the natural reservoir for henipaviruses [61]. Only a few studies have successfully isolated NiV virus from bats. Isolation has been reported from the urine of P. vampyrus [62] and P. hypomelanus [35] in Malaysia and $P$. lylei in Cambodia [63], but at very low prevalence, with only 1/769 samples yielding a virus isolate in the Cambodia study. Such low prevalence could be a factor for the inability to isolate NiV in test samples of bats in other studies. RNA positive PCR results have been obtained for $P$. vampyrus in Indonesia [64] and P. lylei in Thailand [65], which identified both NiV-Malaysia and NiV-Bangladesh RNA sequences. NiV RNA has also been detected in P. giganteus in India [66] and P. vampyrus and Rousettus amplexicaudatus in East Timor [58]. Of particular interest to the EU is the identification of henipavirus antibodies in Myotis daubentonii in China [67], as this species is also found across much of Europe, although it should be noted that NiV specific RNA was not detected in this study and virus isolation was not attempted.

While NiV is predominantly associated with Asia there is increasing evidence for the presence of related viruses in Africa. Paramyxovirus RNA related to $\mathrm{HeV}$ and $\mathrm{NiV}$ has been detected in Eidolon helvum bushmeat in the Republic of Congo [68] and in the faeces and urine from roosting E. helvum bats in Ghana [61,69]. Viral concentrations were estimated to be low using RT-PCR assays [61]. Other studies have identified henipavirus antibodies in Eidolon dupreanum and Pteropus rufus in Madagascar [70]. A recent study combined genetic and serological analyses to determine the extent of connectivity among E. helvum populations across central Africa. Antibodies to henipaviruses were present in bats from all locations with henipavirus seroprevalences reported to be between $25 \%-85.7 \%$, with an overall average of $41.6 \%$ [71]. However, the presence of infection on isolated islands suggested that large population size and connectivity may not be responsible for viral persistence. These studies do not confirm the specific presence of infectious $\mathrm{NiV}$ virus in bats in continental Africa and Madagascar, but they now constitute a reasonably substantial body of work, from a number of independent sources, which suggest increasingly strong evidence for the presence of henipaviruses in bats that have a geographical range outside of Asia and Oceania.

MARV: Table 2 shows a summary of reported testing for MARV in bat species. There are several studies reporting the prevalence of MARV in bats in caves in Africa including the countries of Gabon, Uganda and the Democratic Republic of Congo (DRC) [13,72-76]. MARV is now considered endemic in R. aegyptiacus bats in Gabon [76] and, in general, those bat species which serve as potential reservoirs for MARV are endemic to regions of Central Africa. There is little evidence for the potential of MARV to occur outside Africa at this point, although there are few published reports of testing for this virus on other continents; a study in India showed that none of 140 bats tested, including P. giganteus $(n=31)$, Cynopterus sphinx $(n=30)$ and Megaderma lyra $(n=79)$, were positive by PCR for MARV RNA [66]. Within Africa, there are also reports of antibody or RNA evidence of MARV infection in bat species other than R. aegyptiacus, such as Rhinolophus eloquens, Miniopterus inflatus [13] and Hypsignatus monstrosus [75], but reports are less frequent. This highlights the importance of knowledge on the exact species of bats for the purpose of risk assessment, suggesting the main zoonotic risk is likely from $R$. aegyptiacus. In an experimental study, MARV was found to be present 
in the blood and saliva of viraemic R. aegyptiacus bats but not in their faeces or urine [56], suggesting that close contact between adjacent bats of the same species within the roost may be important for MARV transmission. MARV RNA has also been reported in a pooled liver, spleen, lung extract from a female $R$. aegyptiacus fruit bat in Kenya in 2007, although tissues from other bats including $75 R$. aegyptiacus from two locations were negative [77]. From an EU perspective, $R$. aegyptiacus are known to be present in Cyprus [78] and Turkey [79] and populations were found in the wild in Tenerife in the early 2000s, as a result of escaped captive animals [80], before being effectively eradicated by 2009. There is no reported evidence to suggest presence (or absence) of MARV in these populations.

Bat host heterogeneity of virus prevalence is important both in terms of further spread of infection within the roost and spill-over to humans, e.g., through being hunted for bushmeat. Some fruit bat colonies in trees in Ghana have up to 1 million bats, so the prevalence may vary spatially within the colony [81]. Fruit bat colonies in caves with more than 40,000 R. aegyptiacus bats are structured with juveniles more likely to be exposed to bat droppings due to their peripheral positions within the colony [74]. A study on active infection of MARV in a bat cave in Uganda found a higher prevalence in older juvenile bats $(12.4 \%)$ than younger juveniles $(2.65 \%)$ or adults $(2.4 \%)$, the older juveniles were six months old at the time of capture and younger juveniles three months old [74]. Thus, an important consideration is whether juveniles and adult bats have different behaviors that would affect the onward transmission of MARV. For example, are older juvenile bats and non-breeding adult bats more likely to range further in migration (and hence spread disease to other hosts) than younger juveniles or the breeding adults, or to be caught by bushmeat hunters (as they are less experienced in survival)? 
Table 1. Summary of outbreaks in humans and results of testing for NiV in bats.

\begin{tabular}{|c|c|c|c|c|}
\hline \multirow{2}{*}{$\begin{array}{c}\text { Location } \\
\text { Bangladesh }\end{array}$} & \multirow{2}{*}{$\frac{\text { Human outbreaks }}{[41-43,82]}$} & \multicolumn{2}{|c|}{ Results of testing for $\mathrm{NiV}$ in bats } & \multirow[t]{2}{*}{ Bat species tested } \\
\hline & & Antibodies & {$[42,49]$} & \\
\hline \multirow{2}{*}{ India } & \multirow{2}{*}[46,83]{} & Antibodies & {$[84]$} & P. giganteus, \\
\hline & & RNA, Antibodies & [66] & P. giganteus \\
\hline \multirow{4}{*}{ Malaysia } & \multirow{4}{*}{ [33] } & Antibodies, Virus isolation & [62] & P. vampyrus \\
\hline & & Antibodies & [36] & P. hypomelanus, E. spelaea, C. brachyotis, S. kuhlii, P. vampyrus \\
\hline & & Virus isolation & [35] & P. hypomelanus \\
\hline & & Antibodies \& RNA & [85] & P. hypomelanus (Antibodies only), P. vampyrus \\
\hline Singapore & [86] & - & & - \\
\hline Indonesia & - & RNA, antibodies & [64] & P. vampyrus \\
\hline \multirow{2}{*}{ Thailand } & \multirow{2}{*}{ - } & Antibodies & [87] & P. hypomelanus, P. vampyrus, P. lylei, H. larvatus, \\
\hline & & RNA & {$[65,87]$} & P. lylei, H. larvatus \\
\hline Viet Nam & - & Antibodies & [88] & R. leschenaultia, Cynopterus sphinx \\
\hline Cambodia & - & Antibodies, virus isolation & [63] & P. lylei \\
\hline China & - & Antibodies & [67] & $\begin{array}{l}\text { R. leschenaultia, } H . \text { armiger, } H . \text { Pomona, Miniopterus spp., } M \text {. } \\
\text { daubentonii, } M . \text { ricketti, } R \text {. affinis , } R \text {. sinicus }\end{array}$ \\
\hline Papua New Guinea & - & Antibodies & {$[89,90]$} & D. magna, P. alecto, P. conspicillatus \\
\hline East Timor & & RNA & {$[58]$} & P. vampyrus, $R$. amplexicaudatus \\
\hline Madagascar & - & Antibodies & [70] & E. dupreanum, P. rufus, \\
\hline Ghana & & Antibodies & [91] & E. helvum, Epomophorus gambianus, Hypsignathus monstrosus \\
\hline Africa & - & Antibodies & {$[60,71]$} & E. helvum \\
\hline
\end{tabular}


Table 2. Summary of outbreaks in humans and results of testing for Marburg virus (MARV) in bats.

\begin{tabular}{|c|c|c|c|c|}
\hline Location & $\begin{array}{c}\text { Human } \\
\text { outbreaks }\end{array}$ & \multicolumn{2}{|c|}{ Results of testing for MARV in bats } & Bat species tested \\
\hline Angola & {$[92,93]$} & - & & - \\
\hline DRC Congo & [94] & RNA, antibodies & [13] & $\begin{array}{l}\text { Rousettus aegyptiacus, Rhinolophus eloquens, } \\
\text { Miniopterus inflatus }\end{array}$ \\
\hline Uganda & [54] & $\begin{array}{l}\text { RNA } \\
\text { RNA, antibody, virus isolation, } \\
\text { immunohistochemical }\end{array}$ & $\begin{array}{l}{[73]} \\
{[74]}\end{array}$ & $\begin{array}{l}\text { R. aegyptiacus } \\
\text { R. aegyptiacus, Hipposideros spp. }\end{array}$ \\
\hline Zimbabwe * & [55] & - & & - \\
\hline Kenya & [95] & RNA & [77] & R. aegyptiacus \\
\hline Gabon & - & $\begin{array}{l}\text { RNA } \\
\text { RNA \& antibodies } \\
\text { Antibodies }\end{array}$ & $\begin{array}{l}{[76]} \\
{[72]} \\
{[75]}\end{array}$ & $\begin{array}{l}\text { R. aegyptiacus } \\
\text { R. aegyptiacus } \\
\text { R. aegyptiacus, Hypsignathus monstrosus, } \\
\text { Micropteropus pusillus, Epomops franqueti }\end{array}$ \\
\hline
\end{tabular}

* Human case was identified on return to South Africa, but initial infection was thought to be in Zimbabwe. 


\subsection{Estimation of NiV and MARV "Import Risk” Areas}

Based on data gathered in Tables 1-2, those countries of the world where there is evidence of recent $\mathrm{NiV}$ or MARV infection in humans or bats are highlighted in Figure 2. We define that a country is positive for human infection only if it has had a reported human case in the last 10 years (i.e., since 2003). Such a period of time without a reported case suggests that while there may still be potential for a human case in the country itself, the risk of import to the EU is extremely low. Thus, Malaysia and Singapore are not considered positive for NiV and South Africa and Kenya are not considered positive for MARV. Given the issues regarding use of serological positive results as an indicator of current virus presence, we do not consider serological positive results alone to be an indication of current viral presence in bats for this analysis. Information from the IUCN red list website is used to determine the geographical range of those bat species known to have been naturally infected [12], as there is a potential for undetected viral presence in these countries. It can be seen that while recent human infections of both NiV and MARV appear to be limited in geographical range (the red areas in Figure 2), there are a number of countries where bats have been identified as having the virus, but no human infection has been reported. It is also noted that the full geographical range of these bat species is extensive and in the case of $R$. aegyptiacus encroaches on the south-east boundary of Europe, although the range of Pteropus bats is much further east. However, if species serologically positive for henipaviruses are considered then $M$. daubentonii would be included and the geographical range would be much wider, encompassing Europe and Australia.

Figure 2. Maps showing countries with reported evidence of human and/or bat infection and countries where bat species associated with infection are present, for NiV (top) and MARV (bottom).

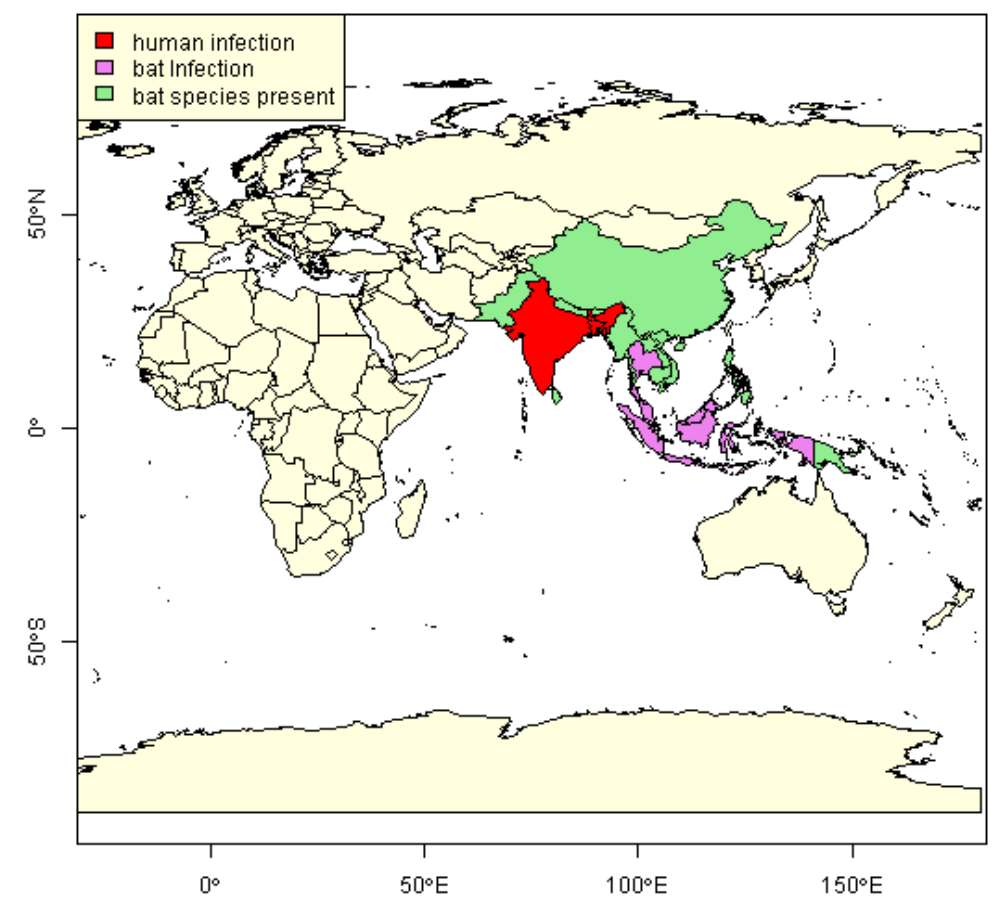


Figure 2. Cont.

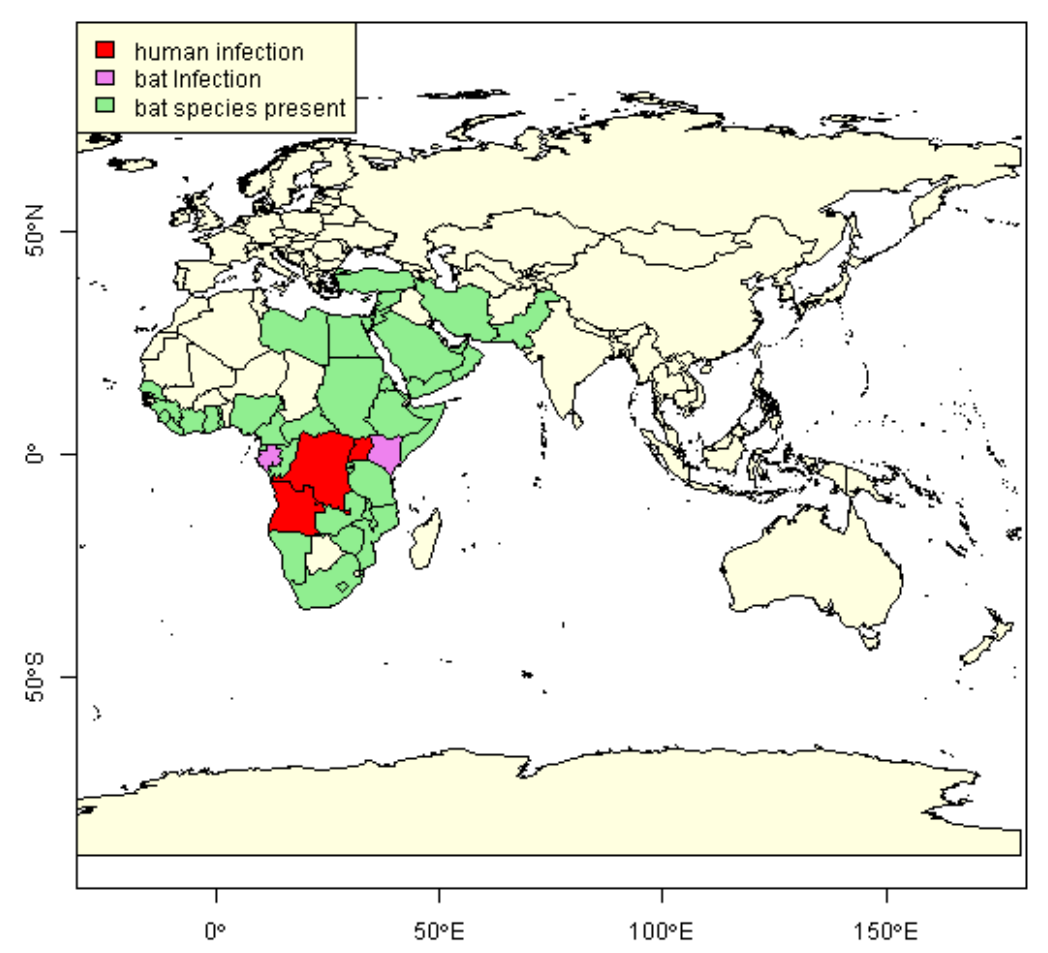

\subsection{Evidence of Viral Load in Bats}

Viral load is a measure of the number of viral particles present in an organism or bodily fluid, e.g., the mass/volume of bat faeces, urine, saliva or bushmeat. The virus may be quantified in a number of ways including plaque-forming units (pfu), tissue culture infectious dose $50 \%$ units $\left(\mathrm{TCID}_{50}\right)$ or number of genome copies. Currently there are no published dose-response curves that convert pfu or $\mathrm{TCID}_{50}$ units in to risk of infection in humans or livestock animals. Furthermore, the genomic copies may not all be equally infectious (due to the mutant spectrum) and some may be defective. It is not clear whether dispersion of the virions lowers the risk of transmission. However, the viral load is an important factor in a release assessment for any virus because it directly affects the risk of transmission.

NiV: While the studies mentioned previously demonstrate the likelihood of a continual reservoir of $\mathrm{NiV}$ in many countries, the actual prevalence of bats currently shedding virus may be very low. As such, data on viral load is limited. However, with the application of real-time PCR, henipavirus-related sequences ranging from 110 to 34,000 genome copies per $0.3 \mathrm{~cm}^{3}$ and $1.8 \times 10^{6}$ per $\mathrm{mL}$ of bat urine have been reported [68]. Experimental studies have also been conducted in other animals. Titres of up to $10^{5} \mathrm{pfu} / \mathrm{mL}$ from brain and basal turbinates and $10^{4} \mathrm{pfu} / \mathrm{mL}$ from trachea swabs were obtained from $\mathrm{NiV}$ infected piglets [96], with lower levels found in lung and spleen and shedding peaks during the first week post inoculation. Titre data are also available for NiV strains from Bangladesh and Malaysia in experimentally infected rodents [33,34].

MARV: One study reported that no viraemia or presence of MARV RNA could be detected in various tissues collected from $R$. aegyptiacus bats experimentally inoculated through oral or nasal routes [56], but subcutaneous and intraperitoneal inoculation resulted in high levels detected in plasma $\left(10^{3}\right.$ to $\left.10^{4} \mathrm{TCID}_{50} / \mathrm{mL}\right)$ for five to nine days post inoculation, with titres up to $10^{6.5}$ and $10^{6.0} \mathrm{TCID}_{50} / \mathrm{g}$ 
in the liver and spleen respectively. Virus was also occasionally detected in lung, heart, kidney and salivary glands with loads up to $10^{5.6} \mathrm{TCID}_{50} / \mathrm{g}$. Ranges for $\mathrm{TCID}_{50} / \mathrm{mL}$ of MARV in tissues of naturally-infected R. aegyptiacus in Uganda have also been derived from a standard curve of diluted stock virus using Q-RT-PCR [74]. High values of 50,000-1,500,000 TCID $\mathrm{T}_{50} / \mathrm{mL}$ were obtained from liver, spleen and lung whilst values of $5-100 \mathrm{TCID}_{50} / \mathrm{mL}$ were obtained from multiple tissues including blood and intestines.

\subsection{Seasonality}

A potential factor affecting the prevalence of viruses, regarding the risk of zoonotic transmission, is seasonal pulsing, or oscillations of prevalence, with peaks in prevalence at specific times of the year. Periods of higher risk are relevant to EU incursion as they will affect factors such as the probability of EU tourists contacting an infected bat and thus impact on routes such as human travel to and from NiV and MARV areas. Indeed, seasonal pulses of MARV circulation in juvenile $R$. aegyptiacus bats coincide with periods of increased risk of human infection [74]. The influx of susceptible young is a crucial driver of infection dynamics and bat reproduction and survival are thought to be major drivers of bat disease dynamics [97]. Many bat species exhibit highly synchronised parturition which can dramatically alter population contact rates and susceptibilities. Sex differences in behaviour and distribution of bats during times of the year when the potential for disease transmission is greatest may also have important implications for disease dynamics [97,98]. The role of bat torpor in infection dynamics is largely unstudied [97]. Torpor typically reduces pathogen replication rates and hence lengthens the incubation periods. A study found a clear indication for torpor being a key factor in allowing perpetuation of rabies virus through the hibernation period, through prolonged incubation period and reduced mortality [99]. This enabled the virus to persist in the population until susceptible individuals from the annual birth pulse could become infected and continue the cycle. Migration and coloniality may also be important drivers of disease dynamics [97], altered migration behaviour may result in declining immunity within specific colonies which could lead to more explosive $\mathrm{HeV}$ epidemics [100].

$\mathbf{N i V}$ : There is evidence of a seasonal pattern for spillover of NiV to humans; a review of all human outbreaks of NiV between 1998 and 2009 found that, except for the initial event in Malaysia, they all occurred in the first five months of the year [65]. A longitudinal study in Thailand found the Bangladesh strain of NiV was dominant in the urine of P. lylei bats, with highest recovery of RNA in May [65]. In two sites, the Bangladesh strain was almost exclusively detected between April and June while the Malaysian strain was found dispersed during December to June. Breeding of the bats (including mating and birthing) occurs in December to April, and may not be the only factor involved in bat transmission.

There is some evidence that pregnant and lactating Pteropus scapulatus and P. conspicillatus females had a significantly higher risk of $\mathrm{HeV}$ infection $[98,100]$ resulting in a seasonal pattern due to seasonality of reproduction of these bats. A study on an orchard in New South Wales investigated the legal shooting of Pteropus poliocephalus [20], found that the majority of bats shot were female (ratio 1:1.75) and that $65 \%$ of these females were lactating. This suggests that pregnant and/or lactating females are more likely to be foraging for food and coming into contact with crops/orchards, which 
could not only be eaten by horses, but also could contribute to seasonality of human spillover for viruses such as NiV Bangladesh, for which oral transmission to humans through date palm sap is a route. The wild date palm produces sap seasonally from mid-October to mid-March and winter (December to early February) is the traditional date palm sap gathering season in Bangladesh. Outbreaks of NiV generally coincide with this season, appearing between December and May.

MARV: A study of MARV in R. aegyptiacus in the Python cave in Uganda predicted an oscillating biannual pattern of bat prevalence in the cave, with peaks in February and March. These peaks in prevalence coincided with the birthing seasons of the bats in the cave and the temporal clustering of previous reported spillover events of MARV into humans [74]. PCR data showed distinct oscillating pulses of MARV infection in older juvenile bats ( $\sim$ six months of age) peaking in February and August that temporarily coincided with the peak twice-yearly birthing seasons. The authors speculate that the MARV pulses reflect the pulses of newly weaned bats which populate the "low-lying" roosting areas where they are infected and may pass infection amongst themselves [74]. As they age, and are recruited into the adult population, their colony positions are taken by the next generation of juvenile bats. It is not clear whether the oscillation peaks in juvenile bats coincide with other environmental/ecological factors affecting the bats such as local shortage of fruit or migration.

\subsection{Survival of Virus/Duration of Infection}

Knowledge of survival of virus in different media and under different environmental conditions is important for assessing the concentrations of virus on contaminated fruit and infected bushmeat over time and ultimately the risk to humans. This can be used to predict the concentrations of virus on the surface of fruit after export by taking into account the duration of transport to the EU. Duration of infection in both humans and bats is also important when considering the probability of shedding infectious virus on arrival in the EU.

NiV: The incubation period for NiV in humans has been reported to be as much as 10 days [46]. Surveillance in Bangladesh in 2013 found that among secondary cases, who had a single exposure to $\mathrm{NiV}$, the delay between exposure to onset of illness ranged from 6-16 days, with a median incubation period of nine days [41]. The incubation period following a single intake of raw date palm sap to onset of illness varied between 2-12 days, with a median of seven days. A laboratory study on persistence of henipaviruses under various environmental conditions found that they were sensitive to $\mathrm{pH}$, temperature and desiccation [101]. The study showed a 3-4 $\log _{10}$ inactivation of henipaviruses in fruit juice (lychee, pawpaw and mango) over three to four days, although titres were still detectable after three days. There were also large variations in the half-life of the virus at different temperatures and $\mathrm{pH}$ values; e.g., in Mango flesh, the half-life of NiV was 0.2 hours for $\mathrm{pH} 3.5$ at $37{ }^{\circ} \mathrm{C}$ but 30.3 hours for $\mathrm{pH} 5$ at $22{ }^{\circ} \mathrm{C}$. For the purpose of risk assessment it is the rate of inactivation which is important, rather than the limit of survival, which depends on the starting titre.

MARV: Investigation of the 1975 outbreak of MARV in Germany suggested that the incubation period could be as much as nine days [26]. An experimental study on the effects of MARV on the common marmoset (Callithrix jacchus) found that animals became febrile after 5-6 days [102]. An experimental study looking at MARV, Zaire ebolavirus (ZEBOV) and Reston ebolavirus (REBOV), demonstrated survival for long periods in liquid media at both room temperature and $4{ }^{\circ} \mathrm{C}$, with virus 
recoverable from glass and plastic surfaces over three weeks after the start of the experiment [103]. Similar decay rates were found for MARV and ZEBOV, while REBOV had significantly better survival within an aerosol. Although data for survival of filoviruses on fruit are not available, a study looking at survival of poliovirus, simian rotavirus and feline calicivirus in the UK found prolonged periods of survival on fresh fruit and vegetable produce at refrigeration temperatures $\left(4-8{ }^{\circ} \mathrm{C}\right)$, extending beyond the shelf life of the product [104]. Survival at $22{ }^{\circ} \mathrm{C}$ was poorer, but some viruses remained viable for over a week. Removal of viruses using conventional chlorine washing could give more than $3 \log _{10}$ reduction, but was only $<1 \log _{10}$ for poliovirus. However, it should be noted that these are non-enveloped viruses, and may, therefore, have different survival properties to the enveloped filoviruses.

\section{Routes of Introduction to the EU}

\subsection{Human Travel}

Human-human transmission has been identified for both NiV and MARV. This, combined with incubation periods that could be over a week [26,46], suggest that human travel could be an important route for transmission of bat-borne zoonotic viruses into the EU. The recent MERS-CoV cases in the EU highlight the risk of virus introduction from human travel [27]. There has been one high profile case of tourism leading to an introduction of MARV into the EU [17,18]. A similar, but non-fatal, incident from a person who visited the same bat cave in Uganda also occurred in the USA [52]. Neither incident resulted in identified infection in other individuals.

Data from Eurostat show that there are large numbers of people travelling between the EU and areas where NiV and MARV have been reported, both by air and by sea [105]. The number of immigrants from these areas settling in EU countries is generally increasing and they will naturally have strong ties to their homeland. For example, the UK censuses of 2001 and 2011 show an increase in both number and percentage of the population of England reporting to be of Indian, Pakistani, Bangladeshi and African ethnicity [106]. Combined, the Indian, Pakistani and Bangladeshi ethnicity groups make up $5.5 \%$ of the England population and 12\% of the population of London in 2011 and similar data show that there has been an increase in the number of people reporting to be born in these countries [106]. One could generally expect the individuals and their friends and families to have frequent trips to and from their native countries. Data from the UK in 2006 suggested that out of 58,100 trips to the UK made by individuals using a Bangladeshi passport, 20,600 were made by people returning after a temporary leave of absence [107].

Figure 3 shows the migration into the EU from the NiV and MARV countries identified in Figure 2. It is apparent that, in terms of migration from NiV countries, the UK has the highest influx of migrants of all EU countries, while from MARV countries it is France. Further analysis showed that the majority of Bangladeshi migrants go to the UK. This might suggest that when considering the risk from humans entering the EU from Bangladesh, the UK is more likely to be at risk (before considering the impact of border control measures). Previous research suggests that historically the Bangladeshis that travelled to the EU were predominantly from Sylhet [107], an area in the North East with very few reports of human $\mathrm{NiV}$ cases, although more recently this may no longer be the case. It should be noted 
that some airports, such as Heathrow, London, act as hubs for passengers going on to other destinations, which may lead to an overestimate for individual MSs. However, an infected individual may be a risk even if only passing through the airport, as they will still likely have contact with airport staff and other passengers.

Figure 3. Percentage contribution of 2012 EU member states (MS) total passengers on board international extra-EU air passenger transport, between NiV (left) and MARV (right) regions, identified in Figure 2 for 2012. Data from Eurostat (International extra-EU air passenger transport by reporting country and partner world regions and countries [avia_paexcc]) [105].

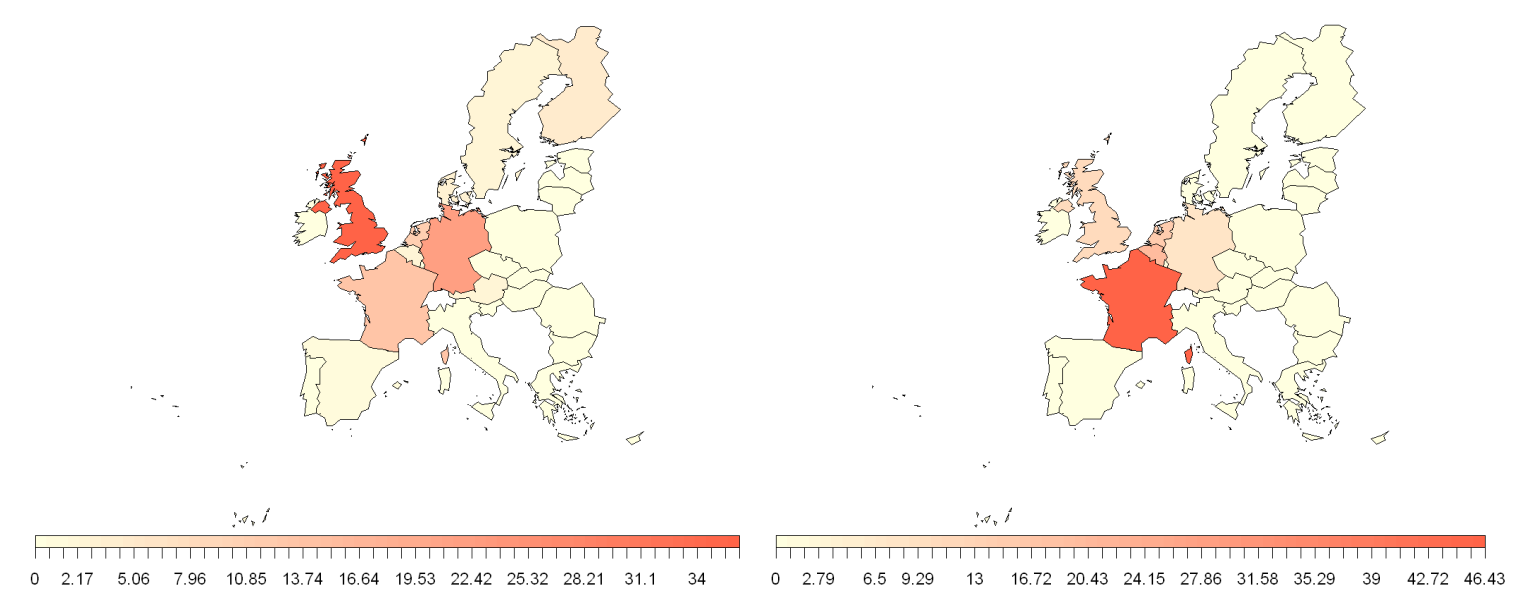

A study looking at the risk of human-human transmission of viral haemorrhagic fevers (VHF), including MARV, on airplanes found only a few events of VHF cases in the literature and no documented infection in follow up contacts [108]. The study suggested that contact trace back should be undertaken for passengers and crew with direct contact with an infected individual, passengers seated within one seat of the case and cleaning staff responsible for cleaning the section occupied by the case. However, trace back of passengers seated more than one seat away from the infected individual was not considered necessary. This suggests that close contact is thought necessary for human-human transmission and so not everyone on an aircraft with an infected individual is likely to be at risk. As such, this would mean that spread of the virus to multiple locations in an EU MS, due to the dispersion of multiple individuals infected during the flight, is unlikely. However, the lack of data regarding VHF on flights and subsequent reliance on expert opinion in this study suggests that there is fairly high uncertainty surrounding the conclusions and further evidence should be sought, particular with regard to other viruses; factors such as stronger capability for airborne transmission could lead to different conclusions.

Tourism may have specific risks independent of other human travel. People who travel to foreign countries on holiday are likely to be there for only short periods of time, e.g., 1-2 weeks and some, particularly ecotourists, may visit bat caves or colonies, returning home soon afterwards. Entering such areas carries the potential risk of direct contact with infected bats and contamination of shoes and clothing with potentially contaminated bat guano/faeces. There is a documented incident, in the Python cave in Uganda, of this leading to MARV infection [17,18], but there are numerous unofficial reports of similar such events. Tourists are perhaps also more likely to be unaware of the risks of virus 
transmission, and therefore unaware of the appropriate precautionary measures. An author of this paper recently returned from West Africa where they witnessed tourists entering an occupied bat cave and having contact with fresh bat guano. The tourists were not aware of the potential risks of virus transmission. However, the recent case of infection of a wildlife biologist with a novel paramyxovirus highlights that there is still a risk for people who are aware of and carrying out appropriate safety precautions [8]. The short duration that tourists generally spend away means that, if infected, it is likely that they will return to the EU before clinical symptoms have developed, and there is little time for decay of pathogens in guano or indeed loss of guano from the clothing or shoes.

\subsection{EU Trade}

It is well established that foodborne zoonoses can pose a threat to human health. Pathogens may be present in products destined for human consumption either through infection of the source product in the natural environment (e.g., contamination of growing crops by infected animals or infection of animal tissues to be consumed while the animal was alive) or cross contamination of the product during processing, typically with urine or faeces. For viruses such as NiV and MARV, while cross-contamination during transportation could result in the presence of virus in other products, the most likely products to be contaminated are those that are associated with outbreaks, i.e., fruit and pig meat. While pig meat has not been directly associated with human infection, live pigs were identified as the source of human infection in the NiV-Malaysia outbreak, although pigs in Malaysia are now considered free of NiV [7]. MARV has not been associated with infection in any livestock animals to our knowledge (MARV is known to infect primates which have been found in bushmeat seizures [109], but in this section we only consider animal products that would be traded legally for food). Drinking raw data palm sap, or alcoholic beverages made from it, have been identified as risk factors for human $\mathrm{NiV}$ infection in Bangladesh [22,46,47], primarily due to the risk of direct contamination of the sap by the local Pteropus bats. We have found no evidence of official trade of either of these products to the EU, although it is possible that individuals may bring alcoholic beverages with them in their personal belongings (the raw date palm sap ferments very quickly so is less likely to be brought over to the EU). While there are a number of products that involve its use, such as palm sugar, there are no reports of human infection as a result of consumption of such products. This suggests that the processing that takes place during the preparation of such products, in the case of palm sugar the sap is generally boiled, mitigates the risk.

Fruit bats are known to feed on a wide range of crops and they are often considered pests due to feeding in commercial orchards, although their importance in pollination is recognized [110,111]. A study on a vineyard in India found the old world fruit bat $C$. sphinx was responsible for $>90 \%$ damage to crops at the periphery of the vineyard [21]. As such, it is common practice to protect commercial crops through the use of measures such as netting or shooting; one study on a stone fruit orchard in Sydney, Australia, consisting of four hectares of nectarine trees, where shooting was known to occur in order to protect the orchard, found a total of 164 dead or injured flying foxes over 14 days at the time when the nectarine crop was ripening and being harvested [20]. NiV-Malaysia was isolated from fruit on Tioman island, and contamination of fruit by bats is thought to be a potential route for the infection of pigs during the Malaysian NiV outbreak [35]. A number of outbreaks in Bangladesh have been 
linked with consumption of date palm sap [22], with the sap likely being contaminated with bat urine or saliva. While the date palm sap is the only identified foodborne source of human NiV infection in Bangladesh, bats could potentially have contact with, and contaminate with saliva or urine, any unprotected fruit grown in the region. While unlikely, if these crops are exported, there could be a risk of virus introduction into the EU. Transport times can be less than 24 hours by air travel, not long enough to allow significant decay of the virus. This route is less likely for MARV as, to date, it has not been detected in the faeces or urine of either experimentally or naturally infected $R$. aegyptiacus bats $[56,74]$.

FaoStat databases contain details of volumes of trade between EU MSs and extra EU countries [112]. The EU has strong trade links with the NiV and MARV identified areas in Figure 2. While these databases show that there is little trade of pig products from NiV and MARV regions to the EU there is trade of fruit products (e.g., dates, apples, fruit juice). Figure 4 shows the relative volume of trade of fruit products from these areas and EU MSs. The biggest importers from these areas are The Netherlands and the UK, with Germany having a relatively high volume from NiV areas and France from MARV areas. As with the human travel, it should be noted that some countries may act as hubs for trade products, with subsequent further distribution to other destinations.

Figure 4. Percentage contribution of 2010 EU MS fruit and pig product trade from NiV (left) and MARV (right) regions, identified in Figure 2. Trade data from Faostat [112].
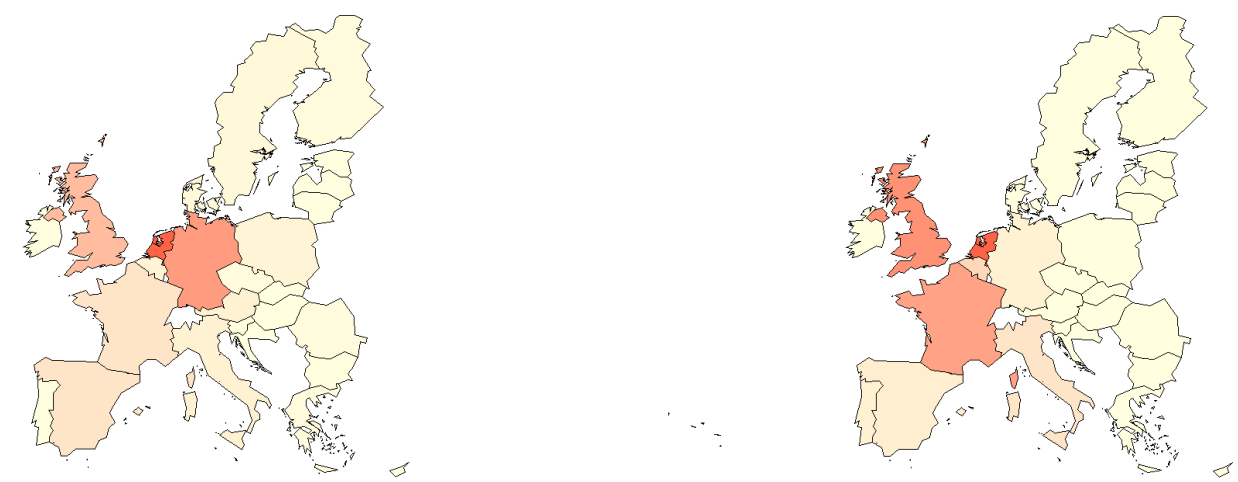

$\therefore \rightarrow$

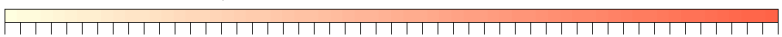

$\begin{array}{llllllllllllll}0 & 1.98 & 4.62 & 6.6 & 8.57 & 11.21 & 13.85 & 16.49 & 19.13 & 21.76 & 24.4 & 27.04 & 29.68 & 32.32\end{array}$

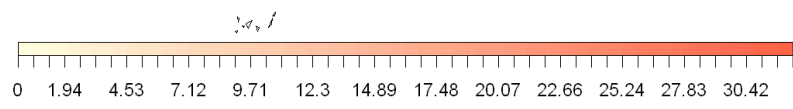

Trade of infected animals for non-food purposes could also pose a risk of viral introduction. MARV has been identified in the African Green Monkey (Cercopithecus aethiops), which have historically been traded for research purposes. There is considerable movement of horses around the world, primarily for sporting events. Horses are known to be susceptible to $\mathrm{HeV}$ with infections in Australia [2], but to date there have been no reported cases of $\mathrm{NiV}$ in horses. Pet travel could also be a risk as the pets could potentially be infected with bat-borne zoonotic viruses in endemic countries. Recently a kitten, infected with rabies virus, entered France from Morocco demonstrating that such events can occur, even though the accompanying certificate of good health did not meet the regulatory provisions for the import of domestic carnivores from Morocco [113]. Data from TRACES suggests that movement of live animals such as pets between NiV or MARV countries (as defined in Figure 2) and the EU are primarily animals not considered a risk of carrying the viruses (e.g., tropical fish) [114]. However, 
there are a number of movements of cats and dogs. An experimental infection study of two cats with the Malaysian strain of NiV found that they started to develop clinical symptoms after five days [96]. One cat developed acute clinical disease while the other recovered. Virus was recovered from the tonsils and urine up to eight days post inoculation. While a very small sample size, and being aware that the experimental challenge dose is likely much higher than would be received in nature, this demonstrates that there is a potential risk of pets bringing the virus back into the EU. There is currently no quarantine regulation for third country pets, although the risk of bringing in pets from $\mathrm{NiV}$ and $\mathrm{HeV}$ areas is recognized by at least some MSs [115].

Bat guano is also a potential trade product; it is sold for use as a fertilizer in several countries including Thailand, Indonesia, Mexico, Cuba and Jamaica [116], and in theory could be imported into the EU. One study reported four of 104 bat guano samples from a bat cave in Ratchaburi Province, Thailand, were positive for Group C betacoronavirus RNA, although none contained NiV RNA [116].

The legal importation of bats could also be a risk. The emergence of wild $R$. aegyptiacus bats in Tenerife was believed to be a result of the escape of captive bats [80]. There are no instances of live bat imports into the EU from NiV countries on TRACES, but there are many instances of bats used in scientific research and zoos. R. aegyptiacus bats, known to be susceptible to MARV, have been kept in zoo's in the EU; in 1997 two such bats died of rabies after being imported from a Dutch zoo to a Danish zoo [117]. Additionally there are reports of $R$. aegyptiacus being kept as pets. However, given the low numbers and the likely increased testing/surveillance of animals destined for these purposes the risk of importation from this route is likely very low.

\subsection{Bushmeat}

Bushmeat is a term used to capture a variety of raw, smoked or partially processed meat that originates from the hunting of a variety of wild animals, including bats. It is well documented that bushmeat is illegally imported into both Europe and the USA [109,118,119] and, as such, it could act as a conduit for pathogen spread. In a recent study, illegal bushmeat imported into the United States was found to contain retroviruses and/or herpesviruses [109] and henipavirus-like RNA has been detected in internal organs of bat bushmeat sampled in the Republic of Congo [68]. The perception of bushmeat as having zoonotic potential is not well recognized among bushmeat hunters, traders and consumers; one study reported that only $24 \%$ of bushmeat hunters in Sierra Leone are aware of the zoonotic disease risk [120] and in a survey on bushmeat in the USA, participants in a focus group considered bushmeat to be a wholesome healthy and safe alternative to commercially produced meat from a shop [121]. In an experimental study of $R$. aegyptiacus bats, MARV was not detected in muscle, brain or skin tissues collected after cardiac exsanguination [56]. This suggests that these tissues (including muscle) are not heavily infected, and that positive results in liver, spleen and kidney were not due to the presence of blood. If confirmed to be the case in naturally occurring infections, it could mitigate the risk of MARV infection from the consumption of bushmeat if internal organs are not eaten.

Hunting of wildlife for food is a widely distributed practice in many parts of the world and constitutes an important source of animal protein for some rural communities. One paper reported that 83.3\% of households in Brazzaville, Congo consumed bushmeat [122] and a survey of municipal 
markets identified 35 different animals species, nine of which it is prohibited to hunt [123]. Economic recession over the past 20 years has driven the commercialisation of bushmeat as a trade item; bushmeat now reaches the international markets as part of the $\$ 159$ billion annual global wildlife trade. The commercial trade in bushmeat occurs across almost all of tropical Africa, Asia and the Neotropics, notably in the densely forested regions of West Africa [124]. Estimates of bush meat harvests in Ghana are around 385,000 tons annually [125]. The bushmeat markets across West Africa are nowadays dominated by small bodied, fast reproducing species such as rodents like the grasscutter (Thryonomys Swinderianus) [126]. There is little officially reported information on the use of bats as bushmeat, a review of 31 survey papers on bushmeat did not report anything on bats [23], but unofficial reports and eye witness accounts suggest it is not uncommon to see bats for sale in African markets. It is possible that bats do not follow a typical bushmeat commodity chain and amounts are therefore underestimated in standard bushmeat surveys [23]. Bats are often hunted for pre-arranged orders and regular customers rather than sale through wholesalers who may prefer to concentrate on larger animals with a higher value-to-weight ratio. One study estimates that 128,000 E. helvum are sold each year in southern Ghana [23]. This involves a commodity chain stretching up to $400 \mathrm{~km}$ and involving multiple vendors.

No official data regarding the size of the bushmeat trade exist as much of the trade is informal or illegal. While much trade is intra-country, trans-border trade does occur through known trade routes throughout the region and there is a limited amount of inter-continental trade from Africa to Europe [127]. Recently a quantity of bushmeat thought to be from the Central African Republic was seized by French Police, and was reported to include bats, although the species were not named [119]. Imports of bushmeat into the UK do occur and mostly take place from those parts of Africa with which the UK has close historical connections, in particular West Africa [124]. Residents of the UK who have their ethnic and cultural origins in Central and West Africa and who are returning from a visit there often bring bushmeat into the UK for their own consumption. In comparison with the domestic market in bushmeat in Central and West Africa the amount of bushmeat coming into the UK represents only a very tiny fraction of the total turnover [128]. A wildlife policy briefing report, which sets out bushmeat preferences in urban Liberia provides a good indication of the sort of bushmeat likely to be imported into the UK, since returnees and visitors to the UK are most likely to buy their bushmeat in urban markets and are likely to reflect current local preferences [129]. The list comprises ungulates, rodents, primates and pangolins. Bats do not feature in the 15 most preferred animals for taste from urban communities in West Africa or in the more generic list of animal involved in the bushmeat trade in West Africa.

Chaber et al. sampled 134 passengers from 29 flights from Central and West Africa to France over 17 days in June 2008 [118]. Fifty-five passengers were found to be carrying fish or domestic meat and nine were carrying bushmeat. Average individual consignments of bushmeat were over $20 \mathrm{~kg}$, compared with 4 and $9 \mathrm{~kg}$ for livestock and fish. Most illegal imports detected by UK Border Agency are small amounts and continue to be typically gifts by travellers visiting family (or returning from visiting family abroad), or seizures from tourists, business people and students travelling to the UK for the first time. Most do not involve deliberately smuggled goods but are made from passengers who are not aware of the current rules and prohibitions in place for Products of Animal origin (POAO) imports [130]. As well as personal carriage, bushmeat may be imported either by postal carriage or 
commercial freight to the EU. HM Revenue and Customs found bushmeat to constitute 3\% of POAO customs seizures for the period 2003-2004. Some bushmeat samples entering EU states from Africa do so from European transit flights, as under the single market goods can travel freely from one member state to another without checks. Thus the situation in any specific member state depends on the effectiveness of border controls in other member states.

The bushmeat from animals hunted in Tropical forests destined to be carried to the EU is likely to be preserved in some form for the duration of the journey. The bushmeat consumed in the UK imported from West Africa is most often either smoked, dried or salted [128]. Because of this processing the initial load of viable organisms on the bushmeat would be expected to be reduced significantly. The average duration of smoking of bushmeat was found to be about 6 hours 30 minutes per day at a maximum temperature of $126.3{ }^{\circ} \mathrm{C}$ [131]. To preserve the bushmeat it may be frozen on arrival in the UK. Freezing in general promotes virus survival and a laboratory study suggested long survival times of MARV at $4{ }^{\circ} \mathrm{C}[103]$.

Throughout Africa and Asia, bats have been used in zootherapy, which is the treatment of human ailments with remedies made from animals and their products. Around $80 \%$ of the population in Africa uses traditional medicine and there is also a growing interest in many developed nations [132]. There is evidence of bats being used for specific ailments in zootherapy and it is possible that they may still be used by migrants in European countries. Treatment of ailments with bats include disorientation in patients with mental illness [133], fertility medicines and post birthing remedies, [134], the use of bat droppings of $P$. giganteus to treat patients with alcohol and drug addiction, [135], and night blindness [136]. In Asia, asthma is the most frequently cited disease for which bats are used as a remedy [137-139]. These therapies are frequently practiced in countries where there is evidence of $\mathrm{NiV}$ infection in bats. Kanda tribal healers in Bangladesh use P. giganteus in formulations for the treatment of fever [140], One pharmaceutical company in Vietnam reportedly imported 50 tonnes of faeces of Rhinolophus bats [141]. In a survey of 802 asthma patients in Singapore primary care clinics on the use of complimentary therapies, 222 patients (27.7\%) had used complimentary medicine out of which 99 (12.3\%) used animal products, 33 (4.1\%) of which had used fruit bats [142,143].

Whilst there is evidence that bats, as bushmeat, are eaten extensively in Africa and Asia there is little evidence of them being internationally traded or brought to the EU in personal possessions; a number of studies have investigated illegal imports of bushmeat, but rarely have bats been among the samples seized. However, these are relatively small studies and do not confirm the extent to which bats are exported as bushmeat. Additionally, other animals, such as monkeys, were identified in the seized samples and are known to be susceptible to viruses such as MARV. A review of possible microbiological hazards associated with the illegal importation of bushmeat concluded that although there was a lack of quantitative data relating to the microbiological risks, the risk of foodborne illness from consumption of bushmeat appeared to be very low and the risk of foodborne illness from cross contamination was also minimal [128]. Normal cooking would probably destroy any viruses and bacteria present although there were no data presented to verify this. The risk from use of bats in zootherapy is not as well understood. However, while the risk of contaminated bushmeat may be low, the consequence could be very high. 


\subsection{Bat Migration}

Migration is a seasonal, usually two-way movement from one place or habitat to another, to avoid unfavourable climatic conditions and/or to seek more favourable energetic conditions [144]. Some bat species are known to migrate large distances and cross national borders [15]. Such behaviour will connect seemingly distant bat populations, and an infected individual could therefore act as a vector to introduce a new virus into a naïve population.

Bat flights are generally short distances for the purpose of foraging, hunting, changing roost sites or social behaviour. Indeed, the majority of bat species in the world are sedentary. Some bats, however, particularly those in the temperate regions of the world, perform annual long distance flights [145]. Bat migration typically occurs along rivers, as shown for bats in Poland and central Slovakia [57,146] and tends to avoid mountainous areas [146].

With regards to bat species and geographical areas relevant to NiV and MARV, in Congo a massive annual fruit bat migration takes place up the Lulua River with hunting of the bats by villagers. Direct exposure to the fruit bats may have led to an outbreak of EBOV in 2007 [53]. Regular mass long-distance migrations have not been reported for $R$. aegyptiacus [147] and a sedentary life history for $R$. aegyptiacus is also supported by the morphological record [148]. In contrast, some E. helvum individuals migrate more than $1000 \mathrm{~km}$ [145], in some cases following the seasonal fluctuation in fruit abundance [149]. Thus, one study reported that that 16 out of 85 (22\%) E. helvum (22\%) were migratory, although 78\% (69 of 85) were non-migratory [150]. The median travel distance of the non-migratory bats was $15 \mathrm{~km}$ (compared to $860 \mathrm{~km}$ for the migratory bats) and similar to the observed daily commuting distances of $R$. aegyptiacus [147]. Based on available data and their own capture information, it was assumed that $E$. helvum has a core distribution in equatorial Africa, with migrations in the northern direction, e.g., Mauritania and Niger from May to September and towards the south e.g., Tanzania, Zimbabwe and Zambia during the months of October and December [150]. Thus, E. helvum from regions of Africa north of the Equator will generally migrate south in the autumn, away from Europe. There is no evidence to suggest that the return migration routes in the spring would take the bats north of the Sahara Desert or that bats that might accidentally fly north (instead of south) in the autumn and reach Europe.

A review of data collected over 73 years from banding of some one million bats within Europe, provides information on which bats cross national borders [145]. These data suggest there are a number of European bat species which migrate seasonally in the range of a few hundred kilometers and four species that are considered long distance migrants (regularly 3000 to $4000 \mathrm{~km}$ in one return flight). The migration routes are generally limited to Europe, with the general trend from north-east to south-west Europe. However, there are data showing movements of Nyctalus noctula from Russia into Bulgaria [145] and it is reported that Pipistrellus nathusii killed in summer and autumn at German wind turbines originated from Estonia or Russia [151]. An occurrence of Vespertilio murinus on a North Sea drilling rig confirmed that bats can fly across large bodies of sea [152]. This raises the question of whether migration of bats from Africa to Europe can occur, for example, across the Strait of Gibraltar. There have been studies in relation to the genetic diversity in Ibero-Moroccan bats, but this does not address the frequency of vagrant African bats flying from Morocco into southern Europe. Colonies of $R$. aegyptiacus, known hosts of MARV, occur in Cyprus and southern Turkey. No banding 
studies have been done and existing knowledge is based on field observations in Europe [145]. In Cyprus, no long distance flights are known, but seasonal altitudinal shifts have been observed [145], which could alter contact rates with other bat species. Thus, despite the growing evidence on migration of bat species within Europe, there are no data to suggest whether migration of bats into Europe from NiV or MARV endemic areas (as outlined in Figure 2) could occur.

A longer term risk factor is the gradual spatial creep of viruses due to transmission to previously uninfected species whose habitat spatially overlaps that of known infected species. For example P. vampyrus are known hosts of NiV. They are not found outside of Asia, according to IUCN red list (see Figure 2), but have been reported in the Shaanxi region of China, close to where M. daubentonii have also been recorded [12]. M. daubentonii are also known to be present across Europe and there is a report of henipavirus antibodies in three of four Myotis bat species at a location in Yunnan Province, southern China in 2006 and 2007. This included nine of 79 M. daubentonii bats [67]. Although pteropid bats are not widespread in China, henipaviruses could be introduced to China by other susceptible bat species whose habitats and ranges overlap those of pteropid bats in neighbouring countries. This raises the question of whether henipaviruses could eventually emerge in European bats. However, there are a number of additional factors that may delay and/or prevent this from occurring, such as mountainous areas providing geographical barriers to interaction of neighbouring bat populations. Indeed according to the IUCN redlist the populations of $M$. daubentonii in China and Europe are not contiguous. It would be interesting to know if bats in south-east Asia migrate in a north-westerly direction to the same regions as those migrant European bat species to give a "virus cross-roads". The risk of EU bat infection with MARV due to overlapping species populations is potentially higher than $\mathrm{NiV}$, due to shorter geographical distances, $R$. aegyptiacus are already present in some European countries where their range may overlap with some migratory European bat species, and the fact that some African fruit bat species (e.g., E. helvum) migrate large distances, although generally within the Sub-Saharan African continent [150]. However, MARV has not been isolated from any bats in Cyprus or indeed Northern Africa, although there have been few published reports of attempts to find MARV outside its normal range. Additionally, MARV has not been isolated from as many different bat species as henipaviruses, so the risk of virus transfer between species may be more limited. This may reflect the ubiquity of molecular receptors for henipaviruses among mammal species.

\subsection{Other Factors}

There are a number of less obvious routes by which bat carcasses or products could enter Europe. For example a bat strike on a long haul aircraft may result in the carcass of the bat being carried long distances across international boundaries. The remains of a bat were found in the wing flap of a Boeing 767 that had flown from Heathrow (UK) to Ben-Gurion airport in Israel [153]. The plane had previously flown from Ghana to London and PCR was used to identify the bat as having highest similarity with $E$. helvum. Flying foxes and other bats were the animal species most often involved in aircraft strikes in Australia between 2002 and 2011 with the majority of air strikes occurring at locations on the east coast of Australia [154]. For the 16 year period (1990-2005) 66,392 strikes were reported to the United States Federal Aviation Authority of which bats were involved in $0.2 \%$ [155]. 
This raises the question of what happens to the bat carcass remains and in particular how it is disposed of. In theory it could drop off the plane on coming into land at the destination airport as the carcass thaws or the wing flaps change position. This raises the possibility of the carcass being eaten by scavenging animals or even pet dogs or cats. Accidental translocations of bats between land masses by ships or aircraft have also been known to occur, almost certainly with a far greater frequency than is actually reported [156]. As some viruses such as coronaviruses can survive for long periods in water [157], bat guano or even dead bats transported in bilge waters of ships could, in theory, serve as route of transport of bat viruses around the world. Another route, again involving aircraft, is where the bat is a stowaway either in the aircraft hold, or even the cabin itself. For example, in 2011, a bat flew through the cabin of a commercial airliner minutes after takeoff during an early morning flight from Wisconsin to Georgia [158].

\subsection{The Effect of a Changing World}

The emergence of new viruses typically reflect change and combinations of events $[159,160]$. In this respect, anthropogenic changes, and in particularly globalization, are drivers. Other changes including farming practice, environmental and climate change not only affect land use but also influence zoological and ecological factors including habitat and food supply. Thus, over time, there may be changes in both the range and distribution of species and intensity and nature of species' interactions. Climate change is associated with extreme weather events such as drought and flood. It is most likely to be linked to the geographical distribution of fruit bats through availability of food sources; the species $P$. nathusii has been observed to be adapting its range in response to recent climate changes [161,162]. This raises the question of how the range and population of fruit bats will change; ultimately, warming could convert forests to grassland savannas which are unsuitable habitats. A shift in the range of pteropid bats due to climate change could have an impact on the circulation of henipaviruses, by putting bats under stress [163]. Pteropus spp. may excrete viruses more often than usual in stressful situations such as when their food is destroyed by climatic events and extreme stress can result in immune suppression which can facilitate increased shedding of the virus [100]. Bats may also spread the virus between regions if they search for food in areas unaffected by flooding. Additionally one study found a significant association with the dry season for spillover events [153].

\section{Discussion}

In this paper we have discussed factors that should be considered when assessing the risk of introduction of two bat-borne viruses, Nipah virus and Marburg virus, into the EU. The routes considered to pose a significant risk of introduction into Europe include human travel, legal trade and illegal importation of bushmeat. A number of other potential routes should also be considered, including, bat strikes on aircraft and bat migration, although migration may not be significant as currently there is little evidence of significant migration pathways into Europe. However, it is unclear whether the absence of knowledge of migration routes into the EU from the countries identified as having infection in bats from Figure 2 is because they do not exist or because their existence has not been comprehensively investigated. Additionally, if NiV or MARV were to spread to areas on a European migration route, such as Russia, then bat migration could become a greater risk. Another, 
more long term risk for introduction to the EU could be transmission between bat species with overlapping distributions; $R$. aegyptiacus are hosts of MARV and present in Cyprus (although MARV is not known to be present in bats in Cyprus), where the range of this species may overlap with some migratory European bat species. It should also be noted that migration could pose a risk for other bat viruses which may be present on these migration routes.

The two viruses discussed in this paper were chosen as they are not known to be present in EU bat populations, but published literature indicates their potential for causing large scale human outbreaks. There are many other bat-borne viruses of similar potential that we do not cover in detail here, but also require in depth consideration, such as Ebola virus, Hendra virus and MERS-CoV. At the time of writing there was limited and not conclusive evidence that MERS-CoV was a bat-borne virus [4,5]. While the risks of introduction of other bat borne zoonotic viruses should be considered on a case by case basis, there will likely be a degree of commonality with the factors and routes discussed in this paper, especially for viruses within the same family as MARV or NiV, namely filoviruses such as EBOV and paramyxoviruses such as $\mathrm{HeV}$.

While there is serological evidence of henipaviruses and filoviruses on multiple continents, the isolation of infectious virus in either bats or humans is currently limited to more confined geographical areas; $\mathrm{NiV}$ in Asia and MARV in Central Africa. Human infection of NiV in particular is currently limited to Bangladesh and West Bengal in India. Given the more widespread identification of NiV amongst bat species and countries in Asia, it is not clear why human outbreaks appear to be confined to this region. This could reflect the route of transmission, sensitivity of surveillance and also perhaps the greater titre of NiV-Bangladesh in bat saliva or urine compared to NiV-Malaysia [33]. Further knowledge of why these viruses do not currently seem to be spreading further, could help in assessing the risk of further spread, including the risk of reaching the EU. While a number of studies report high serological prevalence, actual virus infection in bats is rarely detected. This could explain why human spillover events of NiV-Bangladesh are fairly localised. P. giganteus roosts have been identified within $5 \mathrm{~km}$ of villages in Bangladesh and can consist of around 650 individual bats [50], so even a low prevalence of infection within the roost can mean that there are still sufficient numbers of infected individuals able to contaminate local food sources such as date palm sap.

In this paper we have discussed risks posed by bats, regarding entry of zoonotic viruses to EU, but the ecological importance of bats should also be recognized. Insectivorous bats are responsible for controlling populations of other species considered to be pests such as mosquitoes and other insects, while fruit bats feed on nectar and pollen and so provide an important function as pollinators and/or seed dispersers [164]. While the mass culling of pigs in Malaysia undoubtedly helped to control the NiV outbreak there, culling, or relocation, of wild bats could potentially increase levels of infection [165]. For example, research in Peru found that culling campaigns failed to reduce the seroprevalence of rabies among the studied vampire bat colonies [166]. Additionally culling of bats is considered by many to be unethical and methods are unavailable that comply with current standards of animal welfare. There are many alternative methods to help control virus disease, such as the use of bamboo skirts to prevent NiV contamination of data palm sap in Bangladesh [45,167], limiting potential for indirect contact between livestock and bats at a local level, use of personal protective equipment by investigators dealing with suspect cases and a vaccine against $\mathrm{HeV}$ in horses in Australia [165,168]. 
This review identifies those routes which could provide a potential for introduction of $\mathrm{NiV}$ and MARV into the EU, but does not formally assess the risk associated with each route. For NiV we have shown that, of the EU MSs, the UK has the highest volume of relevant human travel (Figure 3), but the Netherlands has the highest volume of relevant trade (Figure 4), suggesting that the most probable route for introduction may vary between EU MSs. However, to formally assess this it will be important to also take into account virus specific factors such as prevalence, titre and survival and MS specific factors such as border inspections or controls. Therefore, it would be preferential to develop a quantitative risk assessment (QRA), which would require large amounts of data. This review suggests that while data may be lacking to fully assess the risk for routes such as bushmeat, or indeed any other illegal activity, there are sufficient data available to assess legal routes such as volume of trade and human travel.

In general, we found no evidence to suggest that the risk of NiV release to the UK has changed from that reported in a previous qualitative risk assessment [30]. Reported human cases of NiV continue to be limited to Bangladesh and an increase in the number of those cases may be due to enhanced awareness and surveillance. A number of human cases of MARV have been reported in Uganda recently, but again this could be attributed to better surveillance. While there is evidence to suggest henipavirus infection of $M$. daubentonii in China and the presence of $R$. aegyptiacus in the EU country of Cyprus, these are not sufficient factors on their own to warrant undue concern. However, it should be noted that there is a lack of research and surveillance in this area and the evidence for absence of NiV or MARV in bats present in the EU is limited. Human migration patterns continue to change across some areas of the EU, suggesting the frequency of human travel to NiV or MARV areas and corresponding illegal imports of products such as bushmeat may change. This could increase the probability of a "rare event" occurring, such as importation of a bushmeat sample contaminated with virus and, as has been observed in the past, a single introduction event can be enough to cause an outbreak of disease in humans. A better understanding of surveillance sensitivity and biases in reporting, and further investigations of the presence and prevalence of these viruses in both bats and humans should be carried out, as high uncertainty remains about the risks associated with these diseases and how best to prevent or limit the risk of an introduction event.

\section{Acknowledgments}

This work was funded by the European Union FP7 project ANTIGONE (Anticipating Global Onset of Novel Epidemics 278976) and the UK Department for Environment, Food and Rural Affairs (Defra) project SE4213. The authors would also like to thank Trevor Drew and Tony Fooks (AHVLA) for their valuable contributions to this paper.

\section{Author Contributions}

The content of the manuscript was researched, written and prepared by Robin Simons, Paul Gale and Verity Horigan, with ideas and contributions by Emma Snary and Andrew Breed. The idea and design for the project was developed by Emma Snary and Andrew Breed. 


\section{Conflicts of Interest}

The authors declare no conflict of interest.

\section{References and Notes}

1. Luby, S.P. The pandemic potential of Nipah virus. Antivir. Res. 2013, 100, 38-43.

2. Clayton, B.A.; Wang, L.F.; Marsh, G.A. Henipaviruses: An Updated Review Focusing on the Pteropid Reservoir and Features of Transmission. Zoonoses Public Health 2013, 60, 69-83.

3. Martina, B.E.E.; Osterhaus, A. "Filoviruses": A real pandemic threat? Embo Mol. Med. 2009, 1, $10-18$.

4. Memish, Z.A.; Mishra, N.; Olival, K.J.; Fagbo, S.F.; Kapoor, V.; Epstein, J.H.; Alhakeem, R.; Durosinloun, A.; Al Asmari, M.; Islam, A.; et al. Middle East respiratory syndrome coronavirus in bats, Saudi Arabia. Emerg. Infect. Dis. [Internet]. 2013, 19, 1819-1823.

5. Ithete, N.L.; Stoffberg, S.; Corman, V.M.; Cottontail, V.M.; Richards, L.R.; Schoeman, M.C.; Drosten, C.; Drexler, J.F.; Preiser, W. Close Relative of Human Middle East Respiratory Syndrome Coronavirus in Bat, South Africa. Emerg. Infect. Dis. 2013, 19, 1697-1699.

6. Luby, J.P.; Sanders, C.V. Green Monkey Disease ("Marburg Virus" Disease): A New Zoonosis. Ann. Intern. Med. 1969, 71, 657-660.

7. Parashar, U.D.; Sunn, L.M.; Ong, F.; Mounts, A.W.; Arif, M.T.; Ksiazek, T.G.; Kamaluddin, M.A.; Mustafa, A.N.; Kaur, H.; Ding, L.M.; et al. Case-control study of risk factors for human infection with a new zoonotic paramyxovirus, Nipah virus, during a 1998-1999 outbreak of severe encephalitis in Malaysia. J. Infect. Dis. 2000, 181, 1755-1759.

8. Albariño C.G.; Foltzer M.; Towner J.S.; Rowe L.A.; Campbell S.; Jaramillo C.M.; Bird, B.H.; Reeder, D.M.; Vodzak, M.E.; Rota, P.; et al. Novel Paramyxovirus Associated with Severe Acute Febrile Disease, South Sudan and Uganda, 2012. Emerg. Infect. Dis. [Internet] 2014, 20, 211-216.

9. Luis, A.D.; Hayman, D.T.S.; O’Shea, T.J.; Cryan, P.M.; Gilbert, A.T.; Pulliam, J.R.C.; Mills, J.N.; Timonin, M.E.; Willis, C.K.R.; Cunningham, A.A.; et al. A comparison of bats and rodents as reservoirs of zoonotic viruses: Are bats special? Proc. R. Soc. B Biol. Sci. 2013, 280, 20122753.

10. Kurth, A.; Kohl, C.; Brinkmann, A.; Ebinger, A.; Harper, J.A.; Wang, L.F.; Muhldorfer, K.; Wibbelt, G. Novel Paramyxoviruses in Free-Ranging European Bats. PLoS One 2012, 7, e38688.

11. Drexler, J.F.; Corman, V.M.; Muller, M.A.; Maganga, G.D.; Vallo, P.; Binger, T.; Gloza-Rausch, F.; Rasche, A.; Yordanov, S.; Seebens, A.; et al. Bats host major mammalian paramyxoviruses. Nat. Commun. 2012, 3, 12.

12. IUCN. The IUCN Red List of Threatened Species. Version 2013.1. Available online: http://www.iucnredlist.org (accessed on 13 May 2014).

13. Swanepoel, R.; Smit, S.B.; Rollin, P.E.; Formenty, P.; Leman, P.A.; Kemp, A.; Burt, F.J.; Grobbelaar, A.A.; Croft, J.; Bausch, D.G.; et al. Studies of reservoir hosts for Marburg virus. Emerg. Infect. Dis. 2007, 13, 1847-1851. 
14. Epstein, J.H.; Olival, K.J.; Pulliam, J.R.C.; Smith, C.; Westrum, J.; Hughes, T.; Dobson, A.P.; Akbar, Z.; Sohayati Abdul, R.; Misliah Mohamad, B.; et al. Pteropus vampyrus, a hunted migratory species with a multinational home-range and a need for regional management. J. Appl. Ecol. 2009, 46, 991-1002.

15. Breed, A.C.; Field, H.E.; Smith, C.S.; Edmonston, J.; Meers, J. Bats Without Borders: Long-Distance Movements and Implications for Disease Risk Management. Ecohealth 2010, 7 , 204-212.

16. Bausch, D.G.; Borchert, M.; Grein, T.; Roth, C.; Swanepoel, R.; Libande, M.L.; Talarmin, A.; Bertherat, E.; Muyembe-Tamfum, J.J.; Tugume, B.; et al. Risk factors for Marburg hemorrhagic fever, Democratic Republic of the Congo. Emerg. Infect. Dis. 2003, 9, 1531-1537.

17. WHO. Case of Marburg Haemorrhagic Fever imported into the Netherlands from Uganda. Available online: http://www.who.int/csr/don/2008_07_10/en/(accessed on 13 May 2014).

18. Timen, A.; Koopmans, M.P.G.; Vossen, A.; van Doornum, G.J.J.; Gunther, S.; van den Berkmortel, F.; Verduin, K.M.; Dittrich, S.; Emmerich, P.; Osterhaus, A.; et al. Response to Imported Case of Marburg Hemorrhagic Fever, the Netherlands. Emerg. Infect. Dis. 2009, 15, 1171-1175.

19. Chua, K.B.; Chua, B.H.; Wang, C.W. Anthropogenic deforestation, El Nino and the emergence of Nipah virus in Malaysia. Malays. J. Pathol. 2002, 24, 15-21.

20. Divljan, A.; Parry-Jones, K.; Eby, P. Death and inuries to Grey-headed Flying-foxes Pteropus poliocephalus shot at an orchard near Sydney, New South Wales. Zoologist 2011, 35, 698-710.

21. Srinivasulu, C.; Srinivasulu, B. Greater short-nosed fruit bat (Cynopterus sphinx) foraging and damage in vineyards in India. Acta Chiropterologica 2002, 4, 167-171.

22. Rahman, M.A.; Hossain, M.J.; Sultana, S.; Homaira, N.; Khan, S.U.; Rahman, M.; Gurley, E.S.; Rollin, P.E.; Lo, M.K.; Comer, J.A.; et al. Date Palm Sap Linked to Nipah Virus Outbreak in Bangladesh, 2008. Vector Borne Zoonotic Dis. 2012, 12, 65-72.

23. Kamins, A.O.; Restif, O.; Ntiamoa-Baidu, Y.; Suu-Ire, R.; Hayman, D.T.S.; Cunningham, A.A.; Wood, J.L.N.; Rowcliffe, J.M. Uncovering the fruit bat bushmeat commodity chain and the true extent of fruit bat hunting in Ghana, West Africa. Biol. Conserv. 2011, 144, 3000-3008.

24. Lee, R.J.; Gorog, A.J.; Dwiyahreni, A.; Siwu, S.; Riley, J.; Alexander, H.; Paoli, G.D.; Ramono, W. Wildlife trade and implications for law enforcement in Indonesia: A case study from North Sulawesi. Biol. Conserv. 2005, 123, 477-488.

25. Struebig, M.J.; Harrison, M.E.; Cheyne, S.M.; Limin, S.H. Intensive hunting of large flying foxes Pteropus vampyrus natunae in Central Kalimantan, Indonesian Borneo. Oryx 2007, 41, 390-393.

26. Martini, G.A. Marburg virus disease. Postgrad. Med. J. 1973, 49, 542-546.

27. ECDC. Updated rapid risk assessment: Severe respiratory disease associated with Middle East respiratory syndrome coronavirus (MERS-CoV). Eighth update, 6 November 2013. Available online: http://ecdc.europa.eu/en/publications/Publications/mers-cov-risk-assessment-6november-2013.pdf (accessed on 13 May 2014). 
28. Negredo, A.; Palacios, G.; Vazquez-Moron, S.; Gonzalez, F.; Dopazo, H.; Molero, F.; Juste, J.; Quetglas, J.; Savji, N.; Cruz Martinez, M.; et al. Discovery of an ebolavirus-like filovirus in Europe. PLoS Pathog. 2011, 7, e1002304.

29. Warfield, K.L.; Deal, E.M.; Bavari, S. Zoonosis Update Filovirus infections. Javma J. Am. Vet. Med. Assoc. 2009, 234, 1130-1139.

30. Snary, E.L.; Ramnial, V.; Breed, A.C.; Stephenson, B.; Field, H.E.; Fooks, A.R. Qualitative Release Assessment to Estimate the Likelihood of Henipavirus Entering the United Kingdom. PLoS One 2012, 7, e27918.

31. Roche, S.E.; Costard, S.; Meers, J.; Field, H.E.; Breed, A.C. Assessing the risk of Nipah virus establishment in Australian flying-foxes. Epidemiol. Infect. 2014, 4, 1-14.

32. Chang, L.Y.; AbuBakar, S. Nipah virus: Phylogeny and replication. Neurol. Asia 2009, 14, 63-66.

33. Clayton, B.A.; Middleton, D.; Bergfeld, J.; Haining, J.; Arkinstall, R.; Wang, L.; Marsh, G.A. Transmission routes for nipah virus from Malaysia and Bangladesh. Emerg. Infect. Dis. 2012, 18, 1983-1993.

34. DeBuysscher, B.L.; de Wit, E.; Munster, V.J.; Scott, D.; Feldmann, H.; Prescott, J. Comparison of the Pathogenicity of Nipah Virus Isolates from Bangladesh and Malaysia in the Syrian Hamster. PLoS Negl. Trop. Dis. 2013, 7, e2024.

35. Chua, K.B.; Koh, C.L.; Hooi, P.S.; Wee, K.F.; Khong, J.H.; Chua, B.H.; Chan, Y.P.; Lim, M.E.; Lam, S.K. Isolation of Nipah virus from Malaysian Island flying-foxes. Microbes Infect. 2002, 4 , $145-151$.

36. Johara, M.Y.; Field, H.; Rashdi, A.M.; Morrissy, C.; van der Heide, B.; Rota, P.; bin Adzhar, A.; White, J.; Daniels, P.; Jamaluddin, A.; et al. Nipah virus infection in bats (order Chiroptera) in peninsular Malaysia. Emerg. Infect. Dis. 2001, 7, 439-441.

37. Luby, S.P.; Gurley, E.S.; Hossain, M.J. Transmission of Human Infection with Nipah Virus. Clin. Infect. Dis. 2009, 49, 1743-1748.

38. Chua, K.B. Epidemiology, surveillance and control of Nipah virus infections in Malaysia. Malays. J. Pathol. 2010, 32, 69-73.

39. Tan, C.T.; Goh, K.J.; Wong, K.T.; Sarji, S.A.; Chua, K.B.; Chew, N.K.; Murugasu, P.; Loh, Y.L.; Chong, H.T.; Tan, K.S.; et al. Relapsed and late-onset Nipah encephalitis. Ann. Neurol. 2002, 51, 703-708.

40. WHO. Nipah Virus Outbreaks in the WHO South-East Asia Region. Available online: http://searo.who.int/entity/emerging_diseases/links/nipah_virus_outbreaks_sear/en/index.html (accessed on 13 May 2014).

41. IEDCR. Institue of Epidemiology, Disease Control and Research. Nipah infection in 2013. Update on 15 May, 2013. Available online: http://www.iedcr.org/index.php?option=com_content \&view=article\&id=135:23-rd-february-2013-nipah-outbreak\&catid=11 (accessed on 13 May 2014).

42. Homaira, N.; Rahman, M.; Hossain, M.J.; Epstein, J.H.; Sultana, R.; Khan, M.S.U.; Podder, G.; Nahar, K.; Ahmed, B.; Gurley, E.S.; et al. Nipah virus outbreak with person-to-person transmission in a district of Bangladesh, 2007. Epidemiol. Infect. 2010, 138, 1630-1636. 
43. Luby, S.P.; Hossain, M.J.; Gurley, E.S.; Ahmed, B.N.; Banu, S.; Khan, S.U.; Homaira, N.; Rota, P.A.; Rollin, P.E.; Comer, J.A.; et al. Recurrent Zoonotic Transmission of Nipah Virus into Humans, Bangladesh, 2001-2007. Emerg. Infect. Dis. 2009, 15, 1229-1235.

44. Sazzad, H.M.S.; Hossain, M.J.; Gurley, E.S.; Ameen, K.M.H.; Parveen, S.; Islam, M.S.; Faruque, L.I.; Podder, G.; Banu, S.S.; Lo, M.K.; et al. Nipah virus infection outbreak with nosocomial and corpse-to-human transmission, Bangladesh. Emerg. Infect. Dis. 2013, 19, 210-217.

45. Khan, S.U.; Gurley, E.S.; Hossain, M.J.; Nahar, N.; Sharker, M.A.Y.; Luby, S.P. A Randomized Controlled Trial of Interventions to Impede Date Palm Sap Contamination by Bats to Prevent Nipah Virus Transmission in Bangladesh. PLoS One 2012, 7, e42689.

46. Harit, A.K.; Ichhpujani, R.L.; Gupta, S.; Gill, K.S.; Lal, S.; Ganguly, N.K.; Agarwal, S.P. Nipah/Hendra virus outbreak in Siliguri, West Bengal, India in 2001. Indian J. Med. Res. 2006, 123, 553-560.

47. icddr, b. Nipah transmission from bats to humans associated with drinking traditional liquor (tari) in northern Bangladesh, 2011. Health and Science Bulletin 2012, 10, 20 (En), 16-20 (Bengali).

48. Montgomery, J.M.; Hossain, M.J.; Gurley, E.; Carroll, D.S.; Croisier, A.; Bertherat, E.; Asgari, N.; Formenty, P.; Keeler, N.; Comer, J.; et al. Risk factors for Nipah virus encephalitis in Bangladesh. Emerg. Infect. Dis. 2008, 14, 1526-1532.

49. Hsu, V.P.; Hossain, M.J.; Parashar, U.D.; Ali, M.M.; Ksiazek, T.G.; Kuzmin, I.; Niezgoda, M.; Rupprecht, C.; Bresee, J.; Breiman, R.F. Nipah virus encephalitis reemergence, Bangladesh. Emerg. Infect. Dis. 2004, 10, 2082-2087.

50. Hahn, M.B.; Gurley, E.S.; Epstein, J.H.; Islam, M.S.; Patz, J.A.; Daszak, P.; Luby, S.P. The role of landscape composition and configuration on Pteropus giganteus roosting ecology and Nipah virus spillover risk in Bangladesh. Am. J. Trop. Med. Hyg. 2014, 90, 247-255.

51. Chadha, M.S.; Comer, J.A.; Lowe, L.; Rota, P.A.; Rollin, P.E.; Bellini, W.J.; Ksiazek, T.G.; Mishra, A.C. Nipah virus-assodiated encephalitis outbreak, Siliguri, India. Emerg. Infect. Dis. 2006, 12, 235-240.

52. Fujita, N.; Miller, A.; Miller, G.; Gershman, K.; Gallagher, N.; Marano, N.; Hale, C.; Jentes, E. Imported Case of Marburg Hemorrhagic Fever-Colorado, 2008 (Reprinted from MMWR, Volume 58, pp. 1377-1381, 2009). Jama J. Am. Med. Assoc. 2010, 303, 413-415.

53. Leroy, E.M.; Epelboin, A.; Mondonge, V.; Pourrut, X.; Gonzalez, J.P.; Muyembe-Tamfum, J.J.; Formenty, P. Human Ebola Outbreak Resulting from Direct Exposure to Fruit Bats in Luebo, Democratic Republic of Congo, 2007. Vector Borne Zoonotic Dis. 2009, 9, 723-728.

54. Adjemian, J.; Farnon, E.C.; Tschioko, F.; Wamala, J.F.; Byaruhanga, E.; Bwire, G.S.; Kansiime, E.; Kagirita, A.; Ahimbisibwe, S.; Katunguka, F.; et al. Outbreak of Marburg Hemorrhagic Fever Among Miners in Kamwenge and Ibanda Districts, Uganda, 2007. J. Infect. Dis. 2011, 204, S796-S799.

55. Gear, J.S.S.; Cassel, G.A.; Gear, A.J.; Trappler, B.; Clausen, L.; Meyers, A.M.; Kew, M.C.; Bothwell, T.H.; Sher, R.; Miller, G.B.; et al. Outbreak of Marburg virus disease in Johannesburg. Br. Med. J. 1975, 4, 489-493. 
56. Paweska, J.T.; van Vuren, P.J.; Masumu, J.; Leman, P.A.; Grobbelaar, A.A.; Birkhead, M.; Clift, S.; Swanepoel, R.; Kemp, A. Virological and serological findings in Rousettus aegyptiacus experimentally inoculated with vero cells-adapted Hogan strain of Marburg virus. PLoS One 2012, 7, e45479.

57. Furmankiewicz, J.; Kucharska, M. Migration of bats along a large river valley in southwestern Poland. J. Mammal. 2009, 90, 1310-1317.

58. Breed, A.C.; Meers, J.; Sendow, I.; Bossart, K.N.; Barr, J.A.; Smith, I.; Wacharapluesadee, S.; Wang, L.; Field, H.E. The Distribution of Henipaviruses in Southeast Asia and Australasia: Is Wallace's Line a Barrier to Nipah Virus? PLoS One 2013, 8, e61316.

59. Gilbert, A.T.; Fooks, A.R.; Hayman, D.T.S.; Horton, D.L.; Mueller, T.; Plowright, R.; Peel, A.J.; Bowen, R.; Wood, J.L.N.; Mills, J.; et al. Deciphering Serology to Understand the Ecology of Infectious Diseases in Wildlife. Ecohealth 2013, 10, 298-313.

60. Peel, A.J.; McKinley, T.J.; Baker, K.S.; Barr, J.A.; Crameri, G.; Hayman, D.T.S.; Feng, Y.-R.; Broder, C.C.; Wang, L.-F.; Cunningham, A.A.; et al. Use of cross-reactive serological assays for detecting novel pathogens in wildlife: Assessing an appropriate cutoff for henipavirus assays in African bats. J. Virol. Methods 2013, 193, 295-303.

61. Drexler, J.F.; Corman, V.M.; Gloza-Rausch, F.; Seebens, A.; Annan, A.; Ipsen, A.; Kruppa, T.; Muller, M.A.; Kalko, E.K.V.; Adu-Sarkodie, Y.; et al. Henipavirus RNA in African Bats. PLoS One 2009, 4, e6367.

62. Rahman, S.A.; Hassan, S.S.; Olival, K.J.; Mohamed, M.; Chang, L.Y.; Hassan, L.; Saad, N.M.; Shohaimi, S.A.; Mamat, Z.C.; Naim, M.S.; et al. Characterization of Nipah virus from naturally infected Pteropus vampyrus bats, Malaysia. Emerg. Infect. Dis. 2010, 16, 1990-1993.

63. Reynes, J.M.; Counor, D.; Ong, S.; Faure, C.; Seng, V.; Molia, S.; Walston, J.; Georges-Courbot, M.C.; Deubel, V.; Sarthou, J.L. Nipah virus in lyle's flying foxes, Cambodia. Emerg. Infect. Dis. 2005, 11, 1042-1047.

64. Sendow, I.; Ratnawati, A.; Taylor, T.; Adjid, R.M.A.; Saepulloh, M.; Barr, J.; Wong, F.; Daniels, P.; Field, H. Nipah virus in the fruit bat Pteropus vampyrus in Sumatera, Indonesia. PLoS One 2013, 8 , e69544.

65. Wacharapluesadee, S.; Boongird, K.; Wanghongsa, S.; Ratanasetyuth, N.; Supavonwong, P.; Saengsen, D.; Gongal, G.N.; Hemachudha, T. A longitudinal study of the prevalence of Nipah virus in Pteropus lylei bats in Thailand: Evidence for seasonal preference in disease transmission. Vector Borne and Zoonotic Dis. 2010, 10, 183-190.

66. Yadav, P.D.; Raut, C.G.; Shete, A.M.; Mishra, A.C.; Towner, J.S.; Nichol, S.T.; Mourya, D.T. Short report: Detection of Nipah virus RNA in fruit bat (Pteropus giganteus) from India. Am. J. Trop. Med. Hyg. 2012, 87, 576-578.

67. Li, Y.; Wang, J.M.; Hickey, A.C.; Zhang, Y.Z.; Li, Y.C.; Wu, Y.; Zhang, H.J.; Yuan, J.F.; Han, Z.G.; McEachern, J.; et al. Antibodies to Nipah or Nipah-like Viruses in Bats, China. Emerg. Infect. Dis. 2008, 14, 1974-1976.

68. Weiss, S.; Nowak, K.; Fahr, J.; Wibbelt, G.; Mombouli, J.V.; Parra, H.J.; Wolfe, N.D.; Schneider, B.S.; Leendertz, F.H. Henipavirus-related Sequences in Fruit Bat Bushmeat, Republic of Congo. Emerg. Infect. Dis. 2012, 18, 1536-1537. 
69. Baker, K.S.; Todd, S.; Marsh, G.; Fernandez-Loras, A.; Suu-Ire, R.; Wood, J.L.N.; Wang, L.F.; Murcia, P.R.; Cunningham, A.A. Co-circulation of diverse paramyxoviruses in an urban African fruit bat population. J. Gen. Virol. 2012, 93, 850-856.

70. Iehle, C.; Razafitrimo, G.; Razainirina, J.; Andriaholinirina, N.; Goodman, S.M.; Faure, C.; Georges-Courbot, M.-C.; Rousset, D.; Reynes, J.-M. Henipavirus and Tioman virus antibodies in pteropodid bats, Madagascar. Emerg. Infect. Dis. 2007, 13, 159-161.

71. Peel, A.J.; Sargan, D.R.; Baker, K.S.; Hayman, D.T.S.; Barr, J.A.; Crameri, G.; Suu-Ire, R.; Broder, C.C.; Lembo, T.; Wang, L.-F.; et al. Continent-wide panmixia of an African fruit bat facilitates transmission of potentially zoonotic viruses. Nat. Commun. 2013, 4, 2770-2770.

72. Towner, J.S.; Pourrut, X.; Albarino, C.G.; Nkogue, C.N.; Bird, B.H.; Grard, G.; Ksiazek, T.G.; Gonzalez, J.P.; Nichol, S.T.; Leroy, E.M. Marburg Virus Infection Detected in a Common African Bat. PLoS One 2007, 2, e764.

73. Towner, J.S.; Amman, B.R.; Sealy, T.K.; Carroll, S.A.R.; Comer, J.A.; Kemp, A.; Swanepoel, R.; Paddock, C.D.; Balinandi, S.; Khristova, M.L.; et al. Isolation of Genetically Diverse Marburg Viruses from Egyptian Fruit Bats. PLoS Pathog. 2009, 5, e1000536.

74. Amman, B.R.; Carroll, S.A.; Reed, Z.D.; Sealy, T.K.; Balinandi, S.; Swanepoel, R.; Kemp, A.; Erickson, B.R.; Comer, J.A.; Campbell, S.; et al. Seasonal Pulses of Marburg Virus Circulation in Juvenile Rousettus aegyptiacus Bats Coincide with Periods of Increased Risk of Human Infection. PLoS Pathog. 2012, 8, e1002877.

75. Pourrut, X.; Souris, M.; Towner, J.S.; Rollin, P.E.; Nichol, S.T.; Gonzalez, J.P.; Leroy, E. Large serological survey showing cocirculation of Ebola and Marburg viruses in Gabonese bat populations, and a high seroprevalence of both viruses in Rousettus aegyptiacus. BMC Infect. Dis. 2009, 9, 159.

76. Maganga, G.D.; Bourgarel, M.; Ella, G.E.; Drexler, J.F.; Gonzalez, J.P.; Drosten, C.; Leroy, E.M. Is Marburg Virus Enzootic in Gabon? J. Infect. Dis. 2011, 204, S800-S803.

77. Kuzmin, I.V.; Niezgoda, M.; Franka, R.; Agwanda, B.; Markotter, W.; Breiman, R.F.; Shieh, W.J.; Zaki, S.R.; Rupprecht, C.E. Marburg Virus in Fruit Bat, Kenya. Emerg. Infect. Dis. 2010, 16, 352-354.

78. Del Vaglio, M.A.; Nicolaou, H.; Bosso, L.; Russo, D. Feeding habits of the Egyptian fruit bat Rousettus aegyptiacus on Cyrpus island: A first assessment. Hystrix Ital. J. Mammal. 2011, 22, 281-289.

79. Albayrak, I.; Asan, N.; Yorulmaz, T. The natural history of the Egyptian fruit bat, Rousettus aegyptiacus, in Turkey (Mammalia: Chiroptera). Turk. J. Zool. 2008, 32, 11-18.

80. Nogales, M.; Rodriguez-Luengo, J.L.; Marrero, P. Ecological effects and distribution of invasive non-native mammals on the Canary Islands. Mammal Rev. 2006, 36, 49-65.

81. Hayman, D.T.S.; McCrea, R.; Restif, O.; Suu-Ire, R.; Fooks, A.R.; Wood, J.L.N.; Cunningham, A.A.; Rowcliffe, J.M. Demography of straw-colored fruit bats in Ghana. J. Mammal. 2012, 93, 1393-1404.

82. WHO. Nipah Virus Infection. Available online: http:/www.searo.who.int/entity/ emerging_diseases/links/CDS_Nipah_Virus.pdf (accessed on 13 May 2014). 
83. Arankalle, V.A.; Bandyopadhyay, B.T.; Ramdasi, A.Y.; Jadi, R.; Patil, D.R.; Rahman, M.; Majumdar, M.; Banerjee, P.S.; Hati, A.K.; Goswami, R.P.; et al. Genomic Characterization of Nipah Virus, West Bengal, India. Emerg. Infect. Dis. 2011, 17, 907-909.

84. Epstein, J.H.; Prakash, V.; Smith, C.S.; Daszak, P.; McLaughlin, A.B.; Meehan, G.; Field, H.E.; Cunningham, A.A. Henipavirus infection in fruit bats (Pteropus giganteus), India. Emerg. Infect. Dis. 2008, 14, 1309-1311.

85. Shirai, J.; Sohayati, A.L.; Mohamed Ali, A.L.; Suriani, M.N.; Taniguchi, T.; Sharifah, S.H. Nipah virus survey of flying foxes in Malaysia. Jarq Jpn. Agric. Res. Q. 2007, 41, 69-78.

86. Paton, N.I.; Leo, Y.S.; Zaki, S.R.; Auchus, A.P.; Lee, K.E.; Ling, A.E.; Chew, S.K.; Ang, B.; Rollin, P.E.; Umapathi, T.; et al. Outbreak of Nipah-virus infection among abattoir workers in Singapore. Lancet 1999, 354, 1253-1256.

87. Wacharapluesadee, S.; Lumlertdacha, B.; Boongird, K.; Wanghongsa, S.; Chanhome, L.; Rollin, P.; Stockton, P.; Rupprecht, C.E.; Ksiazek, T.G.; Hemachudha, T. Bat Nipah virus, Thailand. Emerg. Infect. Dis. 2005, 11, 1949-1951.

88. Hasebe, F.; Nguyen, T.T.T.; Inoue, S.; Yu, F.X.; Kaku, Y.; Watanabe, S.; Akashi, H.; Dat, D.T.; Le, T.Q.M.; Morita, K. Serologic Evidence of Nipah Virus Infection in Bats, Vietnam. Emerg. Infect. Dis. 2012, 18, 536-537.

89. Field, H.; de Jong, C.E.; Halpin, K.; Smith, C.S. Henipaviruses and fruit bats, Papua New Guinea. Emerg. Infect. Dis. 2013, 19, 670-671.

90. Breed, A.C.; Yu, M.; Barr, J.A.; Crameri, G.; Thalmann, C.M.; Wang, L.-F. Prevalence of Henipavirus and Rubulavirus Antibodies in Pteropid Bats, Papua New Guinea. Emerg. Infect. Dis. 2010, 16, 1997-1999.

91. Hayman, D.T.S.; Suu-Ire, R.; Breed, A.C.; McEachern, J.A.; Wang, L.F.; Wood, J.L.N.; Cunningham, A.A. Evidence of Henipavirus Infection in West African Fruit Bats. PLoS One 2008, 3, 4 .

92. Smetana, J.; Chlibek, R.; Vackova, M. Outbreak of Marburg hemorrhagic fever in Angola. Epidemiol. Mikrobiol. Imunol. 2006, 55, 63-67.

93. Towner, J.S.; Khristova, M.L.; Sealy, T.K.; Vincent, M.J.; Erickson, B.R.; Bawiec, D.A.; Hartman, A.L.; Comer, J.A.; Zaki, S.R.; Stroher, U.; et al. Marburgvirus Genomics and association with a large hemorrhagic fever outbreak in Angola. J. Virol. 2006, 80, 6497-6516.

94. Bausch, D.G.; Nichol, S.T.; Muyembe-Tamfum, J.J.; Borchert, M.; Rollin, P.E.; Sleurs, H.; Campbell, P.; Tshioko, F.K.; Roth, C.; Colebunders, R.; et al. Marburg hemorrhagic fever associated with multiple genetic lineages of virus. N. Engl. J. Med. 2006, 355, 909-919.

95. Smith, D.H.; Johnson, B.K.; Isaacson, M.; Swanepoel, R.; Johnson, K.M.; Killey, M.; Bagshawe, A.; Siongok, T.; Keruga, W.K. Marburg-virus disease in Kenya. Lancet 1982, 1 , 816-820.

96. Middleton, D.J.; Westbury, H.A.; Morrissy, C.J.; van der Heide, B.M.; Russell, G.M.; Braun, M.A.; Hyatt, A.D. Experimental Nipah virus infection in pigs and cats. J. Comp. Pathol. 2002, 126, 124-136.

97. Hayman, D.T.S.; Bowen, R.A.; Cryan, P.M.; McCracken, G.F.; O’Shea, T.J.; Peel, A.J.; Gilbert, A.; Webb, C.T.; Wood, J.L.N. Ecology of Zoonotic Infectious Diseases in Bats: Current Knowledge and Future Directions. Zoonoses Public Health 2013, 60, 2-21. 
98. Breed, A.C.; Breed, M.F.; Meers, J.; Field, H.E. Evidence of Endemic Hendra Virus Infection in Flying-Foxes (Pteropus conspicillatus)-Implications for Disease Risk Management. PLoS One 2011, 6, e28816.

99. Georgea, D.B.; Webb, C.T.; Farnsworth, M.L.; O’Shea, T.J.; Bowen, R.A.; Smith, D.L.; Stanley, T.R.; Ellison, L.E.; Rupprecht, C.E. Host and viral ecology determine bat rabies seasonality and maintenance. Proc. Natl. Acad. Sci. USA 2011, 108, 10208-10213.

100. Plowright, R.K.; Field, H.E.; Smith, C.; Divljan, A.; Palmer, C.; Tabor, G.; Daszak, P.; Foley, J.E. Reproduction and nutritional stress are risk factors for Hendra virus infection in little red flying foxes (Pteropus scapulatus). Proc. R. Soc. B Biol. Sci. 2008, 275, 861-869.

101. Fogarty, R.; Halpin, K.; Hyatt, A.D.; Daszak, P.; Mungall, B.A. Henipavirus susceptibility to environmental variables. Virus Res. 2008, 132, 140-144.

102. Smither, S.J.; Nelson, M.; Eastaugh, L.; Laws, T.R.; Taylor, C.; Smith, S.A.; Salguero, F.J.; Lever, M.S. Experimental respiratory Marburg virus haemorrhagic fever infection in the common marmoset (Callithrix jacchus). Int. J. Exp. Pathol. 2013, 94, 156-168.

103. Piercy, T.J.; Smither, S.J.; Steward, J.A.; Eastaugh, L.; Lever, M.S. The survival of filoviruses in liquids, on solid substrates and in a dynamic aerosol. J. Appl. Microbiol. 2010, 109, 1531-1539.

104. FSA. Project: B02014. The Survival and Decontamination of Viruses on Fresh Produce. Available online: http://www.foodbase.org.uk/results.php?f_category_id=\&f_report_id=625 (accessed on 13 May 2014).

105. Eurostat. Statistics Database. Available online: http://epp.eurostat.ec.europa.eu/portal/page/ portal/statistics/search_database (accessed on 13 May 2014).

106. ONS. Office for national statistics, United Kingdom census data for 2001 and 2011. Available online: http://www.neighbourhood.statistics.gov.uk/dissemination/ (accessed on 13 May 2014).

107. Government., U.D.f.C.a.L. The Bangladeshi Muslim Community in England. Understanding Muslim Ethnic Communities. Available online: http://webarchive.nationalarchives.gov.uk/ 20120919132719/http://www.communities.gov.uk/documents/communities/pdf/1203189.pdf (accessed on 13 May 2014).

108. Gilsdorf, A.; Morgan, D.; Leitmeyer, K. Guidance for contact tracing of cases of Lassa fever, Ebola or Marburg haemorrhagic fever on an airplane results of a European expert consultation. BMC Public Health 2012, 12, doi:10.1186/1471-2458-12-1014.

109. Smith, K.M.; Anthony, S.J.; Switzer, W.M.; Epstein, J.H.; Seimon, T.; Jia, H.; Sanchez, M.D.; Huynh, T.T.; Galland, G.G.; Shapiro, S.E.; et al. Zoonotic Viruses Associated with Illegally Imported Wildlife Products. PLoS One 2012, 7, 71-79.

110. Hodgkison, R.; Balding, S.T.; Zubald, A.; Kunz, T.H. Fruit bats (Chiroptera: Pteropodidae) as seed dispersers and pollinators in a lowland Malaysian rain forest. Biotropica 2003, 35, 491-502.

111. Muscarella, R.; Fleming, T.H. The role of frugivorous bats in tropical forest succession. Biol. Rev. 2007, 82, 573-590.

112. FaoStat. Trade Data. Available online: http:/faostat.fao.org/site/342/default.aspx (accessed on 13 May 2014). 
113. Anon. Immediate notification report: Report reference: Rage-2013-1 REF OIE 14333, Report Date: 04/11/2013, Country: France. Available online: http://www.oie.int/wahis_2/temp/reports/ en_imm_0000014333_20131104_164421.pdf(accessed on 13 May 2014).

114. TRACES. Trade Control and Expert System. Available online: https://webgate.ec.europa.eu/ sanco/traces/ (accessed on 13 May 2014).

115. Defra. Pet Travel: Information for Pet Owners. Available online: https://www.gov.uk/pet-travelinformation-for-pet-owners (accessed on 13 May 2014).

116. Wacharapluesadee, S.; Sintunawa, C.; Kaewpom, T.; Khongnomnan, K.; Olival, K.J.; Epstein, J.H.; Rodpan, A.; Sangsri, P.; Intarut, N.; Chindamporn, A.; et al. Group C betacoronavirus in bat guano fertilizer, Thailand. Emerg. Infect. Dis. 2013, 19, 1349-1351.

117. Ronsholt, L.; Sorensen, K.J.; Bruschke, C.J.M.; Wellenberg, G.J.; van Oirschot, J.T.; Johnstone, P.; Whitby, J.E.; Bourhy, H. Clinically silent rabies infection in (zoo) bats. Vet. Rec. 1998, 142, 519-520.

118. Chaber, A.-L.; Allebone-Webb, S.; Lignereux, Y.; Cunningham, A.A.; Rowcliffe, J.M. The scale of illegal meat importation from Africa to Europe via Paris. Conserv. Lett. 2010, 3, 317-323.

119. Telegraph., T. Frozen porcupines and bats confiscated in Paris exotic food raid. Available online: http://www.telegraph.co.uk/news/worldnews/europe/france/10500982/Frozen-porcupines-andbats-confiscated-in-Paris-exotic-food-raid.html (accessed on 13 May 2014),

120. Subramanian, M. Zoonotic Disease Risk and the Bushmeat Trade: Assessing Awareness Among Hunters and Traders in Sierra Leone. Ecohealth 2012, 9, 471-482.

121. Bair-Brake, H.; Bell, T.; Higgins, A.; Bailey, N.; Duda, M.; Shapiro, S.; Eves, H.E.; Marano, N.; Galland, G. Is that a rodent in your luggage? A mixed method approach to describe bushmeat importation into the United States. Zoonoses Public Health 2013, 61, 97-104.

122. Mbete, R.A.; Banga-Mboko, H.; Racey, P.; Mfoukou-Ntsakala, A.; Nganga, I.; Vermeulen, C.; Doucet, J.-L.; Hornick, J.-L.; Leroy, P. Household bushmeat consumption in Brazzaville, the Republic of the Congo. Trop. Conserv. Sci. 2011, 4, 187-202.

123. Mbete, R.A.; Banga-Mboko, H.; Ngokaka, C.; Bouckacka, Q.F., III; Nganga, I.; Hornick, J.-L.; Leroy, P.; Vermeulen, C. Profile of bushmeat sellers and evaluation of biomass commercialized in the municipal markets of Brazzaville, Congo. Trop. Conserv. Sci. 2011, 4, 203-217.

124. Robinson, J.G.; Bennett, E.L. Hunting for Sustainability in Tropical Forests; Columbia University Press: New York, NY, USA, 2000.

125. Swensson, J. Bushmeat trade in Techiman, Ghana, West Africa. Available online: http://www.ibg.uu.se/digitalAssets/102/102499_swensson-john.pdf (accessed on 13 May 2014).

126. Owusu-Ansah, N. Evaluation of Wildlife Hunting Restrictions on Bushmeat Trade in Five Major Markets around Digya National Park; MA Dissertation, University of Cape Coast, Cape Coast, Ghana, 2010.

127. Bowen-Jones, E. The African bushmeat trade-A recipe for extinction. In Le Commerce de la Viande de Brousse - Le Meilleur Moyen Pour Aller Droit a L'extinction; Publisher: Cambridge, UK, 1998; pp. 48-51.

128. Advisory committee on the microbiological safety of food. Review of Possible Microbiological Hazards that may be Associated with the Illegal Importation of Bushmeat. Available online: http://www.food.gov.uk/multimedia/pdfs/acm741.pdf (accessed on 13 May 2014). 
129. Hoyt, R. Wild Meat Harvest and Trade in Liberia: managing biodiversity, economic and social impacts. Available online: http://www.odi.org.uk/sites/odi.org.uk/files/odi-assets/publicationsopinion-files/3300.pdf (accessed on 13 May 2014).

130. Defra. Annual review of controls on imports of animal products 2010-2011. Available online: https://www.gov.uk/government/publications/annual-review-of-controls-on-imports-of-animalproducts (accessed on 13 May 2014).

131. Makosso-Vheiye, G.; Massamba, A.; Mananga, V.; Massamba, J.; Silou, T. Traditional smoking processes of Bushmeat in Congo (Brazzaville). Int. J. Mol. Zool. 2012, 2, 62-69.

132. WHO. Traditional Medicine Strategy. Available online: http://whqlibdoc.who.int/hq/2002/ who_edm_trm_2002.1.pdf(accessed on 13 May 2014),

133. Lelant, V.; Chenaval, N. Note on a meeting with a marabout from Fadial, Senegal, Western Africa who use bats in his medicine. Afr. Bat Conserv. News 2012, 28, 15-16.

134. Harrison, M.E.; Cheyne, S.M.; Darma, F.; Ribowo, D.A.; Limin, S.H.; Struebig, M.J. Hunting of flying foxes and perception of disease risk in Indonesian Borneo. Biol. Conserv. 2011, 144, 2441-2449.

135. Ghosh, A.K. Ethnobiology: Therapeutics and Natural Resources; Daya Publishing House: Delhi, India, 2008.

136. Zhou, J.; Xie, G.; Yan, X. Encyclopedia of Traditional Chinese Medicines-Molecular Structures, Pharmacological Activities, Natural Sources and Applications: Vol. 4: Isolated Compounds N-S; Springer-Verlag: Berlin, Germany, 2011.

137. Walker, S. Some informal correspondance on local people's medicinal uses of fruit bats. Bat Net Newsl. Newsl. Chiropt. Conserv. Inf. Netw. South Asia 2005, 6, 6.

138. Padmanabhan, P.S.; Sujana, K.A. Animal products in traditional medicine from Attappady hills of Western Ghats. Indian J. Tradit. Knowl. 2008, 7, 326-329.

139. Fujita, M.S.T.; Tuttle, M.D. Flying foxes: Threatened animals of key ecological and economic importance. Conserv. Biol. 1991, 5, 455-463.

140. Lev, E. Traditional healing with animals (zootherapy): Medieval to present-day Levantine practice. J. Ethnopharmacol. 2003, 85, 107-118.

141. Nguyen, D.N.V; Nguyen, T. An Overview of the Use of Plants and Animals in Traditional Medicine Systems in Vietnam; TRAFFIC Southeast Asia, Greater Mekong Programme: Ha Noi, Vietnam, 2008; p. 92.

142. Ng, T.P.; Wong, M.L.; Hong, C.Y.; Koh, K.T.; Goh, L.G. The use of complementary and alternative medicine by asthma patients. QJM 2003, 96, 747-754.

143. Sinha, R.K.S.; Sinha, S. Ethnobiology (Role of Indigenous and Ethnic Societies in Biodiversity Conservation, Human Health Protection and Sustainable Development; Surabhi Publication: Jaipur, India, 2005.

144. Fleming, T.H.; Eby, P. Ecology of bat migration. Bat Ecol. 2003, 4, 156-208.

145. Hutterer, R.; Ivanova, T.; Meyer-Cord, C.; Rodrigues, L. Bat Migrations in Europe: A Review of Banding Data and Literature; Naturschutz und Biologische Vielfalt. 2005, 28, 1-172.

146. Kanuch, P. On the occurrence of Pipistrellus nathusii in central Slovakia. Vespertilio 2012, 16, 165-166. 
147. Tsoar, A.; Nathan, R.; Bartan, Y.; Vyssotski, A.; Dell’Omo, G.; Ulanovsky, N. Large-scale navigational map in a mammal. Proc. Natl. Acad. Sci. USA 2011, 108, E718-E724.

148. Benda, P.; Vallo, P.; Hulva, P.; Horacek, I. The Egyptian fruit bat Rousettus aegyptiacus (Chiroptera: Pteropodidae) in the Palaearctic: Geographical variation and taxonomic status. Biologia 2012, 67, 1230-1244.

149. Richter, H.V.; Cumming, G.S. First application of satellite telemetry to track African straw-coloured fruit bat migration. J. Zool. 2008, 275, 172-176.

150. Ossa, G.; Kramer-Schadt, S.; Peel, A.J.; Scharf, A.K.; Voigt, C.C. The Movement Ecology of the Straw-Colored Fruit Bat, Eidolon helvum, in Sub-Saharan Africa Assessed by Stable Isotope Ratios. PLoS One 2012, 7, e45729.

151. Voigt, C.C.; Popa-Lisseanu, A.G.; Niermann, I.; Kramer-Schadt, S. The catchment area of wind farms for European bats: A plea for international regulations. Biol. Conserv. 2012, 153, 80-86.

152. Stansfield, G. Parti-coloured bat Vespevtilio muvinus L. from a North Sea drilling rig. J. Zool. 1966, 150, 491-492.

153. McFarlane, R.; Becker, N.; Field, H. Investigation of the Climatic and Environmental Context of Hendra Virus Spillover Events 1994-2010. PLoS One 2011, 6, e28374.

154. Parsons, J.G.; Blair, D.; Luly, J.; Robson, S.K.A. Bat Strikes in the Australian Aviation Industry. J. Wildl. Manag. 2009, 73, 526-529.

155. Cleary, C.C.; Dolbeer, R.A.; Wright, S.E. Wildlife Strikes to Civil Aircraft in the United States1990-2005. Available online: http://digitalcommons.unl.edu/cgi/viewcontent.cgi? article $=1006 \&$ context $=$ birdstrikeother (accessed on 13 May 2014),

156. Constantine, D.G. Geographic translocation of bats: Known and potential problems. Emerg. Infect. Dis. 2003, 9, 17-21.

157. Casanova, L.; Rutala, W.A.; Weber, D.J.; Sobsey, M.D. Survival of surrogate coronaviruses in water. Water Res. 2009, 43, 1893-1898.

158. Kazmierczak, J.; Davis, J.P.; Bell, T.R.; Marienau, K.; Cohen, N.J.; Marano, N.; Recuenco, S.; Rupprecht, C.; Buttke, D.; Tack, D.; et al. Rabies risk assessment of exposures to a bat on a commercial airliner-United States, August 2011. Morb. Mortal. Wkly. Rep. 2012, 61, 242-244.

159. Gale, P.; Adkin, A.; Drew, T.; Wooldridge, M. Predicting the impact of climate change on livestock disease in Great Britain. Vet. Rec. 2008, 162, 214-215.

160. Gale, P.; Breed, A.C. Horizon Scanning for Emergence of New Viruses: From Constructing Complex Scenarios to Online Games. Transbound. Emerg. Dis. 2013, 60, 472-474.

161. Benda, P.; Hotoviv, J. Hibernation record of Pipistrellus nathusii in southern Moravia (Czech Republic). Vespertilio 2004, 8, 137-139.

162. Lundy, M.; Montgomery, I.; Russ, J. Climate change-linked range expansion of Nathusius' pipistrelle bat, Pipistrellus nathusii (Keyserling \& Blasius, 1839). J. Biogeogr. 2010, 37, 2232-2242. 
163. Daszak, P.; Zambrana-Torrelio, C.; Bogich, T.L.; Fernandez, M.; Epstein, J.H.; Murray, K.A.; Hamilton, H. Interdisciplinary approaches to understanding disease emergence: The past, present, and future drivers of Nipah virus emergence. Proc. Natl. Acad. Sci. USA 2013, 110, 3681-3688.

164. Izhaki, I.; Korine, C.; Arad, Z. The effect of bat (Rousettus aegyptiacus) dispersal on seed-germination in eastern mediterranean habitats. Oecologia 1995, 101, 335-342.

165. Breed, A.; Field, H.; Perkins, N.; Eby, P.; Cunningham, A.; Prowse, S. Re: Flying foxes carrying Hendra virus in Queensland pose a potential problem for other states. Aust. Vet. J. 2010, 88, N24-N24.

166. Streicker, D.G.; Recuenco, S.; Valderrama, W.; Benavides, J.G.; Vargas, I.; Pacheco, V.; Condori, E.C.; Montgomery, J.; Rupprecht, C.E.; Rohani, P.; et al. Ecological and anthropogenic drivers of rabies exposure in vampire bats: Implications for transmission and control. Proc. R. Soc. B Biol. Sci. 2012, 279, 3384-3392.

167. Nazmun, N.; Mondal, U.K.; Sultana, R.; Hossain, M.J.; Khan, M.S.U.; Gurley, E.S.; Oliveras, E.; Luby, S.P. Piloting the use of indigenous methods to prevent Nipah virus infection by interrupting bats' access to date palm sap in Bangladesh. Health Promot. Int. 2013, 28, 378-386.

168. Department of Agriculture Fisheries and Forestry, Australia. Guidelines for Veterinarians Handling Potential Hendra Virus Infection in Horses. Available online: http://www.daff.qld.gov.au/_data/assets/pdf_file/0009/97713/2355-guidelines-for-veterinarianssept-2013.pdf (accessed on 13 May 2014).

(C) 2014 Crown Copyright. This article is published under the terms of the free Open Government Licence, which permits unrestricted use, distribution and reproduction in any medium, provided the original author and source are credited. See http://www.nationalarchives.gov.uk/doc/open-governmentlicence/open-government-licence.htm. 